\title{
Mineral Industry in Egypt-Part I: Metallic Mineral Commodities
}

\author{
Abdel-Zaher M. Abouzeid ${ }^{1}$, Abdel-Aziz M. Khalid ${ }^{2}$ \\ ${ }^{1}$ Department of Mining, Petroleum, and Metallurgy, Faculty of Engineering, Cairo University, Cairo, Egypt, \\ ${ }^{2}$ Geological Survey and Mineral Resources Authority, Cairo, Egypt. \\ E-mail: abdel.mabouzeid@gmail.com
}

Received November $1^{\text {st }}, 2010$; revised January $24^{\text {th }}, 2011$; accepted January $31^{\text {st }}, 2011$.

\begin{abstract}
The mineral potential in Egypt is quite high. Almost all sorts of industrial minerals, metallic and non-metallic commodities exist in commercial amounts. However, Egypt imports many of the mineral commodities needed for the local mineral industries. The main reason for this is that the investors, either the governmental or the private sectors, refrain from investing into the mineral industry for prospecting, evaluation, and developing the mining and mineral processing technologies. This is because the return on investment in the mining industry is generally low and the pay back period is relatively long compared with easy-to-get money projects. Another reason is the disarray of the mining laws and regulations and lack of administrative capability to deal with domestic and international investors and solve the related problems. Also, lack of skilled personnel in the field of mining and mineral processing is an additional factor for the set back of the mining industry in Egypt. This is why the mining technology in Egypt is not very far from being primitive and extremely simple, with the exception of the underground mining of coal, North of Sinai, and Abu-Tartur phosphate mining, where fully automated long wall operations are designed. Also, the recent gold and tin-tantalum-niobium projects are being designed on modern surface mining and mineral processing technologies. The present review presents an overview of the most important metallic mineral commodities in Egypt, their geological background, reserves and production rates. A brief mention of the existing technologies for their exploitation is also highlighted.
\end{abstract}

Keywords: Egypt Mineral Resources, Geological Aspects; Mining, Mineral Processing, Metallic Ores, Mineral Industry Investments

\section{Introduction}

Egyptian Civilization is one of the most ancient civilizations in the world, which practiced mining and processing of metallic and non-metallic ores. The ancient Egyptians quarried the dimensional stones in a very orderly manner to obtain geometrically shaped blocks with exact dimensions to build tombs, temples and pyramids. They also cut-from extremely hard rocks such as granite, gabbros, and granodiorites-obelisks and blocks for hewing statues and for recording their history on them. They also traced the natural minerals, collected them, and treated them to compose the ever-beautiful painting colors, which stayed bright and persisted weather changes for thousands of years. The Ancient Egyptians had an excellent sense and knowledge about geology, survey, rock mechanics and metallurgical processing. They worked their way out in open pits, open cast, and underground mining. Almost all gold and copper locations known at present were originally discovered and worked out by the
Ancient Egyptians. The technology limitations in mining, and processing, at that time, limited the mining depth, and the overall efficiency of upgrading the ores. The first known underground map (1300 BC), for El-Fawakhir gold mine, is preserved in Turin museum in Italy.

There are evidences that the Ancient Egyptians mined and extracted gold, silver, copper, and zinc. They used these metals in their pure state and/or as alloys to suit certain purposes. They designed and produced several hard alloys such as bronze (90\% Copper and $10 \%$ zinc). They also traced all sorts of gem stones in Sinai, Eastern Desert, and Western Desert. They quarried limestone, granite, marble, breccias, diorites, and granodiorite stones.

Mining in Egypt today, follows almost the same methodology as the Ancient Egyptians used to use thousands of years ago. The main differences are in the introduction of the modern technologies which are available today and were not available then. The underground mines to- 
day are much deeper, drainage of the underground water is readily drained by means of pumps which were not available at that time, the underground atmosphere is conditioned by the up to date conditioning techniques (ventilation and refrigeration), the underground openings are electrically lightened, and the raw materials are mechanically transported [1]. However, the scale of mining in Egypt at present is still small. The largest mining operation, which is the iron ore mining, does not exceed 3 million ton/year [2].

\subsection{Geological Background}

The Egyptian territory is covered by crystalline basement rocks belonging to Precambrian age and Phanerozoic sediments which range in age from Cambrian to Recent. The basement rocks form about $10 \%$ of the land surface and are exposed in South Sinai, Eastern Desert, and South West corner of Egypt [3].

The basement rocks of Southwest corner of Egypt crop out from Egyptian-Libyan borders to Gabal Kamel as continuous low land and ridges. From Gabal Kamel to Aswan, the basement occurs as uplifting inliers. Richter [4] and Richter and Schandelmeier [5] classified Precambrian rocks into three Formations starting from High grade granulites (Granoblastic Formation), overlain by the remobilized Anatexite Formation, and finally the youngest clearly bedded Metasedimentary Formation. All these formations were intruded by granodiorite and porphyritic granite. This classification was used by EGPC and CONOCO [6] in issuing a map of a scale 1:500 000 for the area. Naim et al. [7] used a simpler classification system, where they classified these rocks as old metamorphic rocks of probably Archean age to early Proterozoic. Klerkx [8] and Sultan et al. [9] included amphibolite, ortho- and para- gneisses of granulite and amphibolite facies, which are intruded by calc-alkaline granitoids and gabbros. The late magmatic rocks are clearly related to Pan African. The main economic minerals in this region are Banded Iron Formation probably of Lake Superior Type [10-12].

The basement rocks of Eastern Desert and Sinai form part of Arabian-Nubian shield. More than one scenario were proposed for the evolution of this shield, the more acceptable one is that which assumed that the shield is built up of $\operatorname{arc}(\mathrm{s})$-inter $\operatorname{arc}(\mathrm{s})$ rock association $[13,14]$. The arc associations' complexes encompass the volcanosedimentary group. The arc-inter arc associations are well illustrated by ophiolitic slabs (serpentinized ultramafic rocks, tholeiitic Meta gabbros, mafic metavolcanics), thrusted over the arc complex terrain [15]. The evolution and cratonization of the arc group took place between 900-550 Ma [16]. The arc-inter arc group was intruded by syn-to late- tectonic calc-alkaline dio- rite-granodiorite rocks through tectono-magmatic cycle ended by cratonization, through thrusting, low angle shearing and folding [17]. This stage was culminated by granodiorite intrusion as in Meatiq and Hafafit areas at $612 \mathrm{Ma}$ [18]. The Neoproterozoic crust was subjected to regional NW-SE folding and intruded by granite, G1 [19] and Dokhan volcanics [20]. Hammamat sediments which are derived from volcanic rocks were deposited in intra mountain basins [21]. The tectonic granite (younger granite G2 and G3) [19] was intruded in the final stage of Pan African tectono-magmatism [20]. During rifting stage several ring complexes were intruded as intraplate magmatism which could be emplaced during Paleozoic or younger [22]. During Phanerozoic, three-within-plate volcanic activities namely Katherine Volcanic, Wadi Natash Volcanic, and Tertiary basalts and dolerites are recorded.

The Phanerozoic sediments overlay uncomfortably the basement rocks and cover $90 \%$ of the whole Egyptian territory starting from Paleozoic to Quaternary.

Older Paleozoic rocks crop out near the basement contacts in the Western Desert and in Sinai, but they sink below younger sediments further North and West. In Sinai the section is mostly sandstone usually ferruginous and manganiferous in Um Bogma [23].

Mesozoic sediments are very unequally distributed. Marine Triassic is found in Aref El Naga, whereas continental covers many areas in Egypt. The Jurassic age is well developed in Gabal Maghara and South West of Sinai, Khashm El Galala. Cretaceous sediments are widely distributed and form about $40 \%$ of the Egyptian surface. The deposition of Cretaceous sediments is not only governed by regression and transgression of fall and rise of sea level, but also by renewal uplift of source areas and variations in continuous input linked to tectonism along the continental margin [24] and within the craton [25]. All phosphate deposits and white sands are the economic minerals in Mesozoic.

The Cenozoic in Egypt witnessed three major events: thin distribution in time and space, their mode of deposition, and N-E and S-W changes of facies [23]. The Paleocene and Eocene rocks crop out in the Nile Valley between Luxor and Cairo, Fayioum, Bahariya, Sinai, and North Eastern Desert. Oligocene started with the uplifting of Egyptian Craton with the rise of South Western Desert of Egypt. It is well illustrated in Gabal Qatrani, Gabal Ahmar, Safaga-Quseir area and around Mersa Alam on the Red Sea, Baharia, and West of Nile Valley. Miocene occupies one eighths of the total land surface [26]. Sedimentation was greatly influenced by the tectonic events which led to the formation of the Red Sea [23]. 1t crops out at Red sea, South West of Sinai and North Western Desert. Pliocene is represented in Red Sea hills, Wadi Qena, Mediterranean Sea, Fayoum, Nile Val- 
ley and Nile Delta, and Cairo-Suez district. Quaternary deposits are widely distributed as wadi deposits, sand dunes, and Sabkhas.

\subsection{Economic Metallic Ores in Egypt}

Several metallic ores were recorded in Egypt [27]. In the present time, only iron and ilmenite are under mining while manganese and chromite are mined in small scale. The rest of metallic ores mainly, gold, $\mathrm{Pb}-\mathrm{Zn}, \mathrm{Cu}, \mathrm{Nb}-\mathrm{Ta}$ deposits are still under exploration and re-estimation of ore reserves.

Many attempts were done to classify these ores either on the bases of time of deposition [28-30] or in the frame of metalogenetic aspects [31,32]. The first linking between plate tectonic modeling for Arabian-Nubian shield and mineralization was given by Garson and Shalaby [33]. The latest classification was proposed by Botros and Noor [34] where they classified the Egyptian ore deposits on the bases of tectonic-magmatic stages as follows;

\subsection{Island Arc Stage}

A-Deposits formed in ophiolitic assemblage including $\mathrm{Cu}-\mathrm{Ni}$-Co sulphides e.g. Abu Swayeil copper and Podiform chromite deposits.

B-Deposits formed in primitive island arc including Banded Iron Formations, BIF, and its gold related deposits.

C-Deposits formed in mature island arc including volcanic hosted base metal massive sulphides e.g. gold related deposits such as Um Samuki.

\subsection{Accretional Stage (Orogenic Stage)}

A- Auriferous vein type.

B- Base metal vein type.

C- Titanoferrous iron ore, e.g., Abu Ghalqa ore deposit.

\subsection{Late Orogenic-Extensional Stage}

A- $\mathrm{Cu}-\mathrm{Ni}$ sulphides Gabbro, Akarm

B- Titanoferrous iron ore, Kurabkanci

C-Association with granitic rocks:

-Beryllium, e.g., Um Kabu

-Tin - deposit e.g. Abu Dabbab

-Tungsten, e.g., Igla

-Fluorite, e.g., Homr Akarm

-Auriferous vein deposit, e.g., El Sid

This series of articles provides a statistical summary about the most important mineral commodities in Egypt. It also briefs the geological aspects, the mining, and mineral processing techniques used in the today's mining activities and the scale of the mining operations existing in Egypt. Each commodity is preceded with the related geological conditions and events. The mineral commodi- ties can be classified as metallic and non-metallic deposits $[1,2,11,35-41]$. The most important of these deposits are:

1) Metallic ores such as: iron ores, gold ores, industrial metal oxides ( $\mathrm{Sn}, \mathrm{Ta}, \mathrm{Nb}, \mathrm{W}$, and $\mathrm{Mo}$ ), titanium and titaniferous-iron ores, manganese ores, sulphide mineralization $(\mathrm{Pb}, \mathrm{Zn}, \mathrm{Cu}$, and $\mathrm{Co})$, and chromite.

2) Non-metallic ores such as: phosphate, limestone, dolomite, ornamental stones, quartz rock, white sands, talc, feldspars, kaolin, fire clays, bentonite, gypsum, fluorspar, sands and gravels, magnesite, evaporates (salts), and coal.

The present work is an attempt to shed some lights on the metallic ores in Egypt as a whole and to discuss the technological problems facing their exploitation, i.e., no specific mineralization classification will be strictly followed. The metallic ores, which will be discussed here in, are put according to the priority of their economic impact on Egypt.

\section{Iron Ores in Egypt}

Iron ores in Egypt occur in two forms:

A. Banded Iron Formation (BIF), and

B. Ironstone.

The iron deposits in Egypt are shown in Figure 1 [27]. This figure shows the distribution of iron ores and iron oxide traces all over Egypt. Most of the locations are inter-related in origin to each other. The trend of the iron oxides in Western Desert points out to a common source of the iron deposits in this area.

\subsection{Banded Iron Formation, BIF}

This type of iron mineralization was recorded in Eastern Desert in 13 localities between Safaga in the North and Mersa Alam in the South, and in South Western Desert in the area between Egyptian-Libyan border in the West to Gabal Kamel in the East and extends outside Egypt to the Libyan and Sudanese territories around Gabal Arkenu and around Gabal Kissu, respectively [42].

\subsubsection{Eastern Desert BIF}

The most famous occurrences of BIF in Eastern Desert are Wadi Kareim, Um Nar, Abu Marawat, El Dabbah, Um Ghamis, Gabal El Hadid, Um Shadad, and Abu Diwan. The country rock of BIF is the island arc volcanic (basalt, andesite, and dacite), and volcanoclastic rocks as in Abu Marawat [43]. The volcanoclastic rocks are accumulated with BIF in intra-arc basins and intercalated with BIF in the central part of Eastern Desert. The dimension of BIF band ranges in thickness from few centimeters up to 5 meters with an average thickness of 1.5 $\mathrm{m}$ in most cases.

Um Nar BIF is a good example, where this area has 


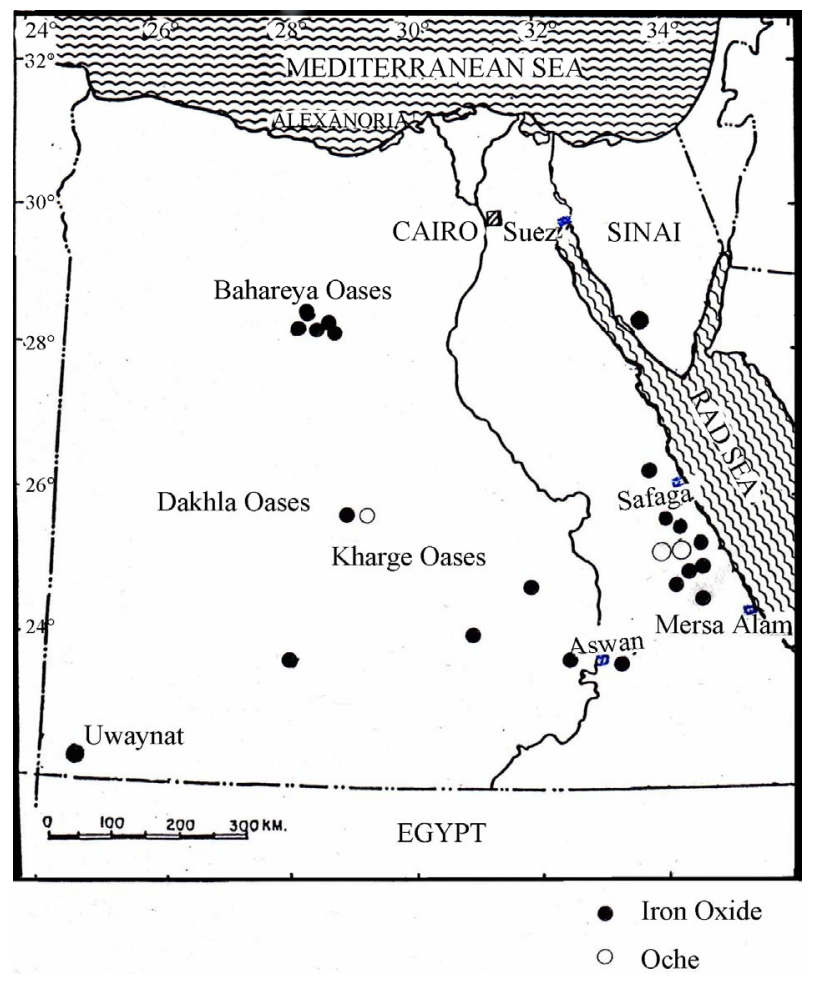

Figure 1. Locations of iron mineral deposits in Egypt [27].

13.7 million tons with iron content up to $45 \% \mathrm{Fe}$ [32]. According to Dardir and El Chimi [44], this area is mainly built of four litholotectonic units: 1-porphyritic quartz granitoids, structurally overlaying a series of tectonically mixed schists comprising acid and intermediate tuffs, biotite, quartz, schists and phyllonite, and Serpentinite which forms Gabal El Mayit ultramafic rocks. Um Nar sequences overlie structurally the serpentinite rocks of Gabal El Mayit. This group is folded into overturned syncline, Figure 2 [45]. Figure 2 shows the complexity of the iron formation at Um Nar and similar iron ore locations in the Eastern Desert. There are extensive folding and faulting systems in the area. This structure reflects the difficulties which may face the mining operations. BIF in all outcrops exhibits oxide facies which is composed of alternative iron rich bands with silica rich bands. Carbonates and sulphides facies also do exist [46,47]. El Dougdoug et al. [47], on the bases of the mineralogy of Gabal El Hadid, stated that BIF exhibits the following formations: 1-hematite-magnetite-jasper as oxide facies, 2-siderite-magnetite-chert as carbonate facies, and 3pyrite-magnetite as sulphides facies. Regarding the origin of BIF, Botros [43] proposed a model for Abu Marawat $\mathrm{BIF}$, where he attributed the formation of BIF to the interaction between volcanically derived fluids and sea water. These fluids were capable to leach iron, silica, and other associated elements including gold from basalt and andesite in early stage of island arc volcanicity (imma- ture island arc).

\subsubsection{Western Desert BIF}

BIF in Western Desert was discovered in two main areas namely Gabal Nazar and Gabal Kamel. At Gabal Nazar area, which lies just to the East of the Libyan borders, the banded iron formation occurs as thin bands $(5-10 \mathrm{~m})$ within amphibolite and quartzo-felsphathic gneisses [12, 38 ] and takes E-W and NE-SW trend. From economic point of view, it is less important due to the intrusion of huge granitic bodies which cut the extension of the ore. Khalid and Diaf $[12,38]$ recorded some gold anomalies in this formation. At Gabal Kamel area, BIF was recorded in the area between latitude $22^{\circ} 00^{\prime}$ to $22^{\circ} 20^{\prime}$ North and longitude $25^{\circ} 30^{\prime}$ to $26^{\circ} 40^{\prime}$ East, which are covered by Archean to early Proterozoic rocks [9]. These metamorphic rocks include garnet-granulite, mafic granulite, para-and ortho-gneisses showing intense deformation manifested by folding and faulting with at least four deformation phases [48]. The whole area had undergone regional metamorphism from garnet granulite to amphibolite facies [4]. Anatexis features are well developed in the area.

The BIF occurs as strongly folded and faulted bands within these Archean to Early Proterozoic high grade metamorphic sequence. The formation attains $300 \mathrm{~m}$ thickness and extends several kilometers in length, Figure $3[7,11,39]$. This figure shows the patchy formation of the iron oxide blocks. These blocks are scattered vertically and laterally. Mining of iron oxides in these areas will be extremely difficult, and removal of the huge inter-bedded quartzite and quartz will be highly costly. It will require highly advanced selective mining techniques.

BIF in this area is classified according to the mode of occurrence into three types: 1-well banded type, 2-brecciated type, and 3-ferruginous chert [39]. The well banded type is the predominant where iron rich bands (magnetite, hematite, and goethite) alternate with microcrystalline silica rich bands (quartz, chert, and jasper). Mineralogical studies revealed that opaque minerals are magnetite, hematite, and goethite which are the main minerals with some sulphides (pyrite, chalcopyrite, arsenopyrite, and covellite). Graphite was recorded in some samples which could be attributed to metamor-phism of carbonate facies [39]. The chemical analyses show that iron oxides range between $16 \%$ and $55.5 \%$ [39]. On the bases of geographic situation and major structural elements and mineralogical characteristics, Khattab et al. [11] classified the BIF in this region into Western, Central, and Eastern zones. They came to a conclusion that the Central and Western parts are, economically, the most promising areas. All the above mentioned authors are inclined to consider this type of BIF as lake Superior 


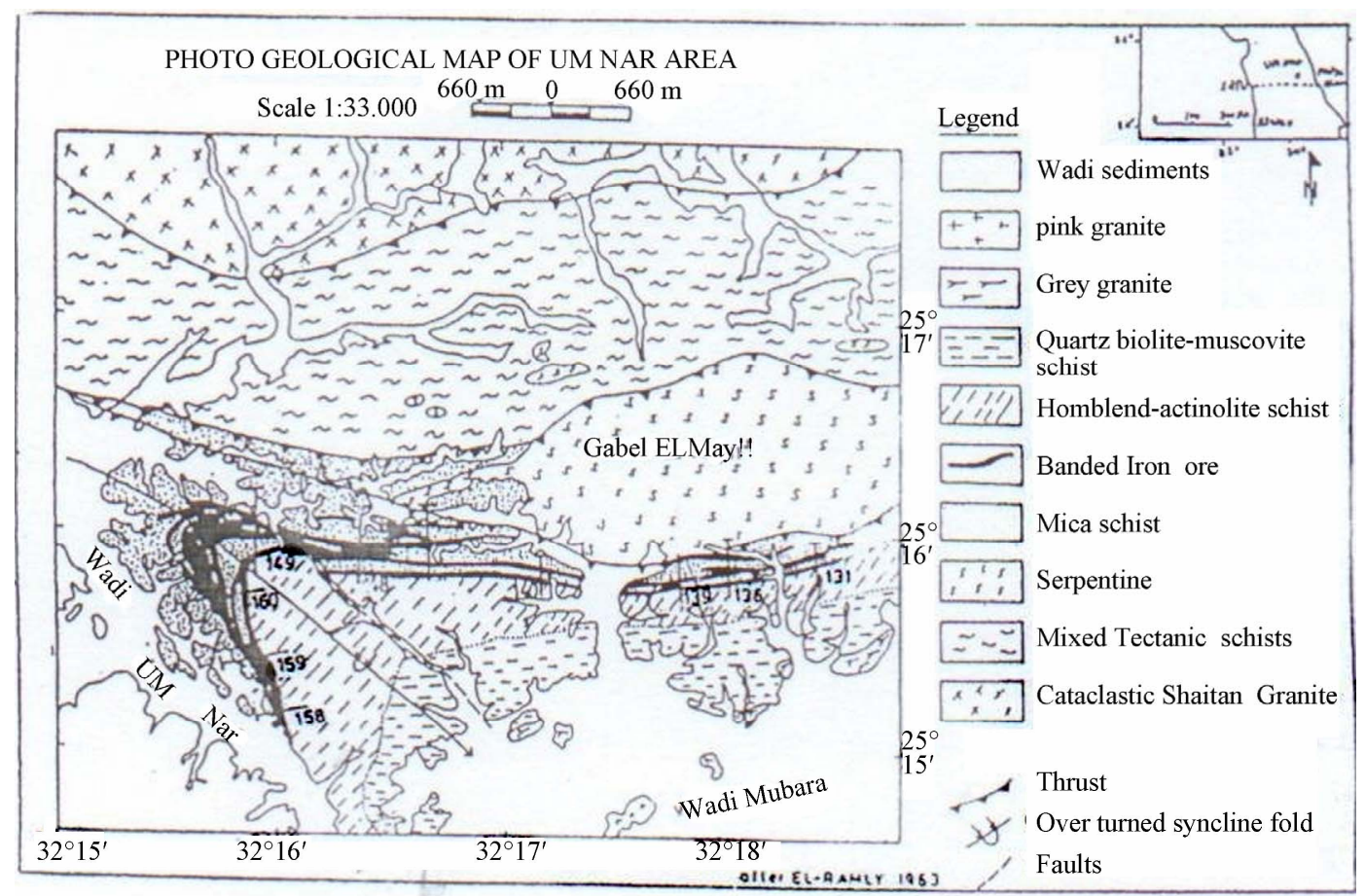

Figure 2. Geological map of Um Narbanded iron formation, Eastern Desert, Egypt [45].

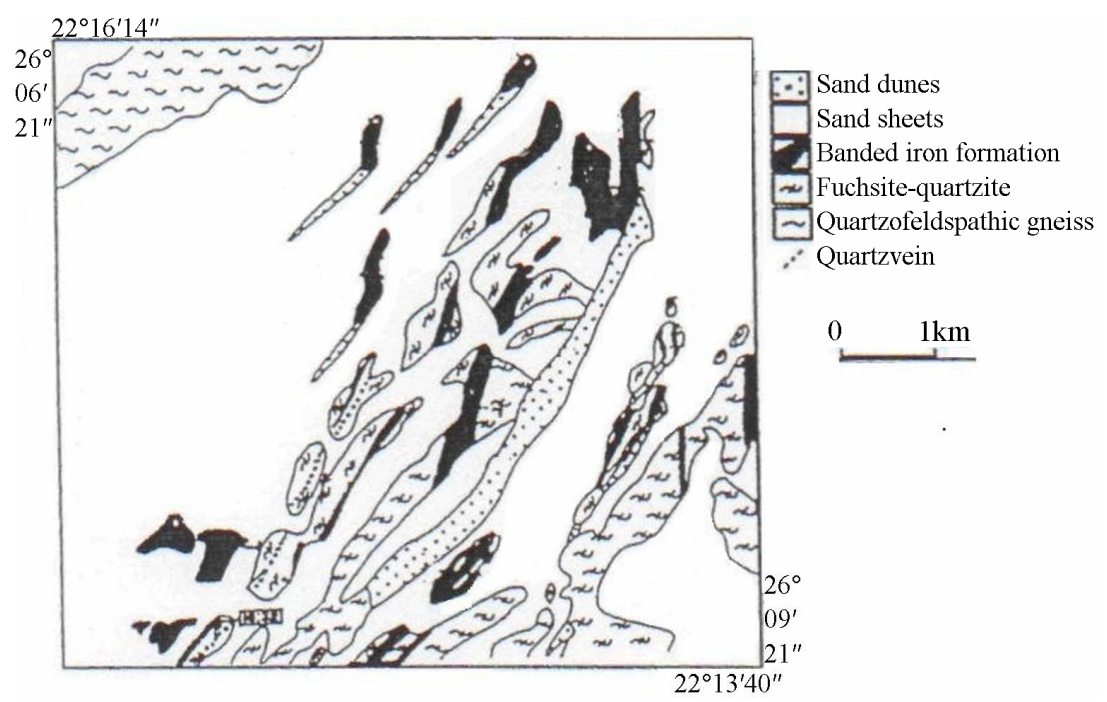

Figure 3. Geological map of Area K 7 in Central Zone of Gabal Kamel BIF [11].

Type of oxide facies and suggested deposition in epicontinental marine basin with free access to the ocean [49].

\subsection{Ironstone Deposits}

Iron stone is the iron ore which is formed mainly withinPhanerozoic sediments and is well represented in Egypt in Bahariya and Aswan iron ores.

Bahariya Iron Ore: Several iron ore deposits are located in Bahariya area, e.g., El Harra, El Heiz, Ghorabi, El Gedida, and Nasser. The iron ore of El Harra belongs to El Harra member of El Haffuf Formation; whereas El Gedida iron ore belongs to Naqb Formation [50-52]. The area is covered by Bahariya Formation (unfossiliferous varicolored sandstone of Cenomanian age) followed by El Heiz Formation (brownish limestone and sandy clay beds), and El Haffuf Formation of sandstone, sandy clay, and ferruginous beds, which are partly taken by the iron ore deposit, Khuman Formation (chalky limestone), and $\mathrm{Naqb}$ Formation of thick limestone beds with few marl and clay associations. The iron content in the ironstone 
deposits ranges from $30 \%$ to $58 \% \mathrm{Fe}$, and the manganese content ranges from $0.7 \%$ to $7.66 \% \mathrm{Mn}$ [52].

The stratigraphic position of Naqb Formation is partly taken by iron ore deposits at El Gedida, El Harra, and Ghorabi; where El Gedida iron ore member belongs to iron deposits of Lower Middle Eocene (Naqb Formation) and the upper Eocene (Abu Maharik Formation. The ore is localized in the crest of anticline [53].

Origin of Ironstone Ores at Bahariya Oases: The origin of the existing Ironstone ores was discussed by several authors [52-58]. El Shazly [59] assumed that the Ghorabi iron ore was derived from the chemical weathering of older rocks. El Bassyouny [52], on the bases of detailed field work, stated that the iron content of $\mathrm{El}$ Harra ironstone deposit increases in iron content towards the fault and decreases gradually northward, away from the fault, where ferruginous limestone crops out, and he believes that the enrichment of iron took place by intense metasomatism replacement which is believed to had taken place in post middle Miocene-Eocene time, probably related to nearby volcanism. On the other hand, El Aref and Lotfy [55] proposed karst genetic for El Bahariya iron ore, where they suggested that the iron deposits were formed through lateritization processes during the senile stage of post Eocene karst event. Karst depressions and excavated unconformity acted as traps where iron oxides are accumulated. Iron deposits together with soil products also form surfacial crust (duricrust), capping and cementing highly subdued and altered carbonate rocks. The evolution of megascopic and microscopic ore fabrics, the oxidation of iron bearing minerals, and their relation to the gangue and weathering products reflect the changes in the moisture regimes and the physicochemical conditions involved during the pedogenesis [55]. Hussein [32] proposed a very important idea, where he considered that most of the folds were generated by faulting affiliated with the Pelsuium mega-shear along which the Bahariya Oases are located [58]. The present authors are inclined to believe in this idea where along this zone iron was recorded by Issawi [59] in Black Hills of high iron content (up to $38 \% \mathrm{Fe}$ ). More iron discoveries are expected along this zone especially to the Southward direction, where the main iron source is Basement rocks (Banded Iron Formation).

Figure 4, shows a map for Bahariya Oases with its iron ore localities as related to each other geographically. Only the exploitable iron ore in Bahariya Oases at El Gedida area, which has little or no overburden. Originally, when mining started in this area in 1972, the minable reserves were estimated accurately by $135 \mathrm{Mt}$. Today, the left minable reserves are estimated by only 63 Mt, which are just enough for about 15-20 years at the present mining rate of 3 to $3.5 \mathrm{Mt} / \mathrm{y}$. The other areas:
Ghorabi, Nasser, El Heiz, and El Harra are of low grade ores and of high manganese content. In addition, these areas have relatively thick overburden.

Aswan Iron Ore: Iron ore in this area was known since Pharaonic time. In recent years it was the main supply of iron ores for the Egyptian iron and steel industry till 1972 when it was replaced by Bahariya iron ore. According to Hussein [32], the ore is a bedded oolitic type of Senonian age in the form of two bands interbedded with ferruginous sandstone and clay capping Precambrian rocks. The thickness of the bands varies from 0.2 to $3.5 \mathrm{~m}$. The main iron minerals are hematite with minor goethite where quartz, gypsum, halite and clay are gangue minerals. The reserve was estimated between 121-135 million tones with average content of $46.8 \% \mathrm{Fe}$ [60]. The ore had been formed under sedimentary lacustrine conditions during Senonian sedimentation. Aswan iron ores were used to feed the steel plant at Helwan from its establishment in 1956 until 1972 when the Bahariya iron ore, from El Gedida area, started to replace Aswan ore in the iron and steel plant at Helwan.

The potentiality of discovering more iron ore is high especially in the area between Bahariya Oases in the North and Uwaynat area in the South on the bases of geological and structural observations. Reserves and production of iron ores in Egypt are shown in Table 1. In this table, it is clear that Egypt is running short of the available indigenous exploitable iron ores, which is mainly in El Gedida area, Bahariya Oases, Western Desert. The Aswan iron ore is high in phosphorus content, in addition to its peculiar formation. The Eastern Desert BIF iron ores are of small quantities (about 50 million tons in total in all localities) spread in a vast area of about $200 \mathrm{~km}^{2}$. Uwaynat BIF iron ore has been recently discovered and not thorough investigations (exploration, reserve estimation, characterization and /or beneficiation) have been carried out. In addition, the area is more than $600 \mathrm{~km}$ far from the inhabited Nile valley area, with little or no infra structure. A preliminary project for mining, processing, and pelletizing of Uwaynat iron ore deposit is being proposed after the discovery of Uwaynat BIF deposits [17,38,48]. Pilot scale mineral processing tests showed that Uwaynat ore may be upgraded to $66 \%$ Fe at a reasonable recovery [39].

The mining method in all producing locations at present is open pit mining [61]. The main iron ore processing plant is at Bahariya Oases (El-Gedida Area) [61]. The plant consists of a jaw crusher followed by a cone crusher to reduce the run-of-mine ore to the maximum size required by the sinter plant at Helwan. Of course, this is waste of energy and cost. The raw ore is transported, with all its gangue content, from the mine to the steel plant for a distance of over $300 \mathrm{~km}$. This represents 


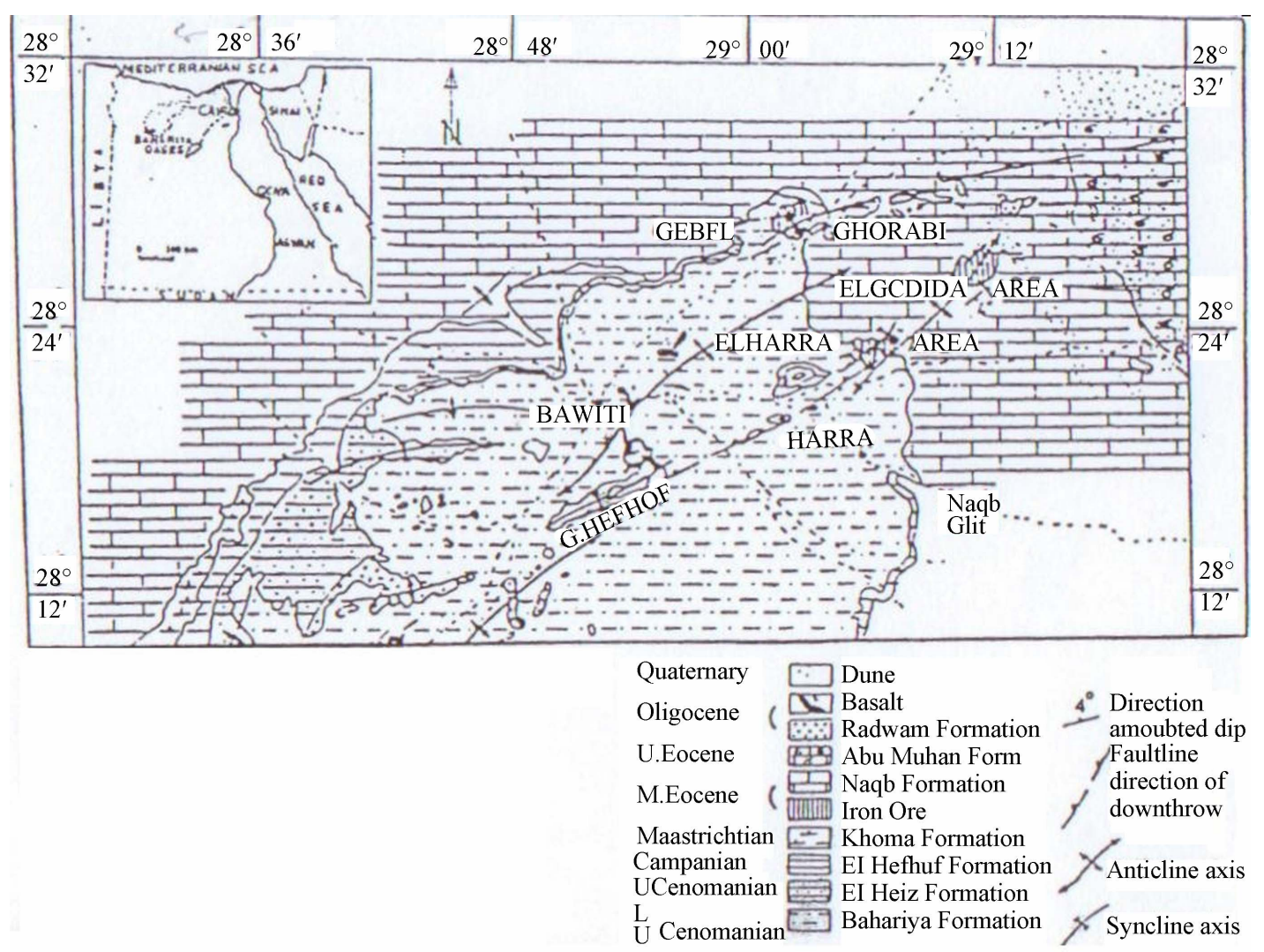

Figure 4. Geological map of El Bahareya Oases. The important iron minerals localities [51].

higher transportation costs, loss of energy in extraction, lower unit productivity, waste of labor efforts, and so on. It could have been more beneficial if the ore is concentrated in the mine site, i.e., raising the iron content of the ore from $52 \% \mathrm{Fe}$ to $65 \% \mathrm{Fe}$. This will overcome all the above drawbacks of using the mined ore as it is. There are modern technologies for upgrading such type of ores. These technologies include flotation, flocculation/flotation, high intensity magnetic separation, and magnetic roasting followed by low intensity magnetic separation.

\section{Gold in Egypt}

Gold is recorded in Egypt in more than 95 occurrences most of them were mined during Pharaonic age. Fifty years ago on ward, extensive efforts were done by the Geological Survey of Egypt (EGSMA) to explore gold in the old mines areas and their vicinity. The earlier work was conducted in co-operation with Russian Experts. Through this exploration work new targets were introduced such as alteration zones around gold bearing quartz veins and banded iron formation. Also new areas outside the known old mines were explored such as South Sinai and South Western Desert [7,38,43,44,62-67 ]. Several attempts were done to classify gold mineralizations, among these is the early classification mentioned by Kochin and Bassyouni [28], where they classified this mineralization on the bases of the mode of occurrence and nature of mineralization into three types namely: 1-dyke type, 2-vein type, and 3-placer deposit. El Ramly et al. $[68,69]$ classified the gold deposits according to their geographic situations into five regions, Figure 5. Figure 5 shows the scattered occurrences of the ancient gold localities in the Eastern Desert from Latitude $28^{\circ}$ North down to $22^{\circ}$ North. It also shows the five geographic regions according to El Ramly classification of the gold deposits in the Eastern Desert. Gold deposits were classified, based on the tectonic setting models applied to the evolution of Arabian-Nubian shield, into four main formations; gold-sulphides formation, skarn gold ferruginous formations, gold sulphide Formations, and quartz vein formation. On the bases of tectonic setting proposed to the evolution of Arabian-Nubian shield, Botros [70] proposed a classification for gold mineralization as summarized in Table 2.

It is obvious from Table 2 that gold mineralization occurs in almost all the island arc and syn-magmatic stage. This simply means that there is no specific lithology that could be responsible for gold mineralization, but certain gold mineralization could be hosted in certain lithology. Up till now, economic gold deposits in Egypt are related to quartz veins and adjacent alteration zones. 
Table 1. Iron ores information [27].

\begin{tabular}{|c|c|c|c|c|c|c|}
\hline Area & Location & Reserves, $\mathrm{M}$ tons & $\begin{array}{c}\text { Produc.., } \\
1000 \text { t/y }\end{array}$ & Average Assay, Fe \% & Associated constituents & Remarks \\
\hline \multirow{3}{*}{ Aswan } & N-E Aswan & 25 & & 44 & \multirow{3}{*}{$\mathrm{Mn}, \mathrm{S}, \mathrm{P}, \mathrm{SiO} 2, \mathrm{Ti}$} & Hematite \\
\hline & S-E Aswan & 300 & 20 & 46 & & +hydrated \\
\hline & West Aswan & na & & 44 & & oxides \\
\hline \multirow{10}{*}{$\begin{array}{l}\text { Eastern Desert } \\
\qquad(\mathrm{BIF})^{*}\end{array}$} & W.Kareem & 18 & - & 45 & \multirow{10}{*}{$\mathrm{Si}, \mathrm{Ti}, \mathrm{P}, \mathrm{Ca}$} & \multirow{10}{*}{$\begin{array}{c}\text { Magnetite+ } \\
\text { Hematite }\end{array}$} \\
\hline & Um Nar & 14 & - & 46 & & \\
\hline & Abu Marwat & 7 & - & 44 & & \\
\hline & W.Dabbah & 6 & - & 38 & & \\
\hline & Um Khamees & 6 & - & 44 & & \\
\hline & G. Elhadid & 4 & - & 46 & & \\
\hline & Abou Rakab & 5.7 & - & 37 & & \\
\hline & El-Hendousi & 0.2 & - & 31 & & \\
\hline & Um Shaddad & 0.3 & - & 48 & & \\
\hline & Sitro & 0.55 & - & 43 & & \\
\hline \multirow{5}{*}{ Bahariya Oases } & Gedida & 90 & 3,000 & 53 & \multirow{5}{*}{$\begin{array}{c}\mathrm{Mn}, \mathrm{S}, \mathrm{P}, \mathrm{Cl}, \mathrm{Si} \\
\mathrm{P}, \mathrm{Si}\end{array}$} & \multirow{5}{*}{$\begin{array}{c}\text { Hematite+ } \\
\text { Geothite+ } \\
\text { Limonite+ } \\
\text { hydrogeotjite }\end{array}$} \\
\hline & Ghorabi & 60 & - & 47 & & \\
\hline & Nasser & 30 & - & 44 & & \\
\hline & Al-Harrah & 35 & - & 45 & & \\
\hline & Al-Haiz & 100 & - & 30 & & \\
\hline \multirow{3}{*}{ Uwaynat (BIF)* } & G.Nazar & $15-300 \mathrm{~m}$ & - & & \multirow{3}{*}{$\begin{array}{l}\mathrm{Si}, \mathrm{Au}, \mathrm{Ag}, \\
\mathrm{Cu}, \mathrm{Pb}, \mathrm{Zn}\end{array}$} & Magnetite+ \\
\hline & G.Kamel & Thickness & - & $12-42$ & & Hematite+ \\
\hline & Ч.АГКеПU & Several kms Extention & - & & & Silicates \\
\hline Black Sands) & Rosetta-Rafah & 400 & - & $2-3$ & $\mathrm{Si}, \mathrm{Ti}, \mathrm{Zr}, \mathrm{Th}$, garnet & Beach sands \\
\hline Sinai & & na & 150 & $\mathrm{Na}$ & & \\
\hline
\end{tabular}

* Banded Iron Formation, BIF.

Most of the old mines have dumps and tailings containing appreciable amount of gold. This may be due to the primitive technologies existed at that time or due to sudden shut down of mines. Gold mineralizations are found in lithified placers, especially along basement sediments contact zones, and disseminated gold, which probably occurs in mafic and intermediate rocks. This postulation should be tested. In this article, only one example is discussed here, Barramiya gold mine.

The Barramiya gold mine represents one of the important gold mines in central Eastern Desert. It lies in midway between Idfu on the Nile bank and Mersa Alam on the Red Sea coast. The mineralization is confined to gold bearing quartz veins and adjacent alteration zone. The country rocks are mainly composed of ophiolitic mélange where serpentinite forms a block in the Western part which is transformed autometasomatically into talccarbonate in the central and Eastern part. The mineralized quartz vein traverses actinolite-tremolite schists and graphite schists. Graphite schists crop out around quartz vein and may be acted as geochemical barrier and play essential role in mineralization. Granitoid rocks of calcalkaline affinity (G1 type) are intruded in North and South of the mine area. The quartz vein takes E-W strike trend with dipping Northward by high angle $\left(75^{\circ}-85^{\circ}\right)$, and occupy the main axis of syncline. The average thickness of the quartz vein is one meter and extends for about 800 meters. The alteration zone around the vein is about 6 meters thick, and mainly consists of intensively altered graphite and tremolite-actinolite schists with ferruginous, sercitization, kaolinazation process. These alterations form zonations arranged as mentioned. Listweanite was formed as lenses and bands as a result of combination of silica and carbonate, and found to be gold bearing spots. This mine has been subjected to detailed exploration work by the Geological Survey of Egypt in co-operation with Russian experts [71]. According to this detailed study, the average gold in the quartz vein is estimated as $1.59 \mathrm{~g} / \mathrm{t}$, alteration zone $2.74 \mathrm{~g} / \mathrm{t}$, and listweanite 1.37 $\mathrm{g} /$ twith total reserve of 30 tons of gold [72]. 
Table 2. Classification of gold deposits [70].

\begin{tabular}{|c|c|c|c|}
\hline Class & Type of deposit & Tectonic environment & $\begin{array}{c}\text { Type of } \\
\text { mineralization }\end{array}$ \\
\hline \multirow[t]{3}{*}{ Strata bound deposit } & a. gold hosted in Algoma type BIF & Immature island arc & $\begin{array}{c}\text { Syngenetic mineraliza- } \\
\text { tion }\end{array}$ \\
\hline & b. Au hosted in tuffaceous sediments & Mature island arc environment & \\
\hline & $\begin{array}{l}\text { c. Au hosted in volcanogenic } \\
\text { massive sulphide deposits }\end{array}$ & & \\
\hline \multirow[t]{12}{*}{$\begin{array}{l}\text { Non-strata bound } \\
\text { deposits }\end{array}$} & A. vein type mineralization & $\begin{array}{c}\text { Continental margin environ- } \\
\text { ment }\end{array}$ & $\begin{array}{c}\text { Epigenetic mineraliza- } \\
\text { tion }\end{array}$ \\
\hline & 1- Auriferous quartz vein hosted in metamorphic & & \\
\hline & rocks and / or granitic surrounded & & \\
\hline & 2- Auriferous quartz veins in sheared & & \\
\hline & ophiolitic ultramafic rocks & & \\
\hline & 3- Auriferous quartz vein as associated & & \\
\hline & with porphyry copper & & \\
\hline & $\begin{array}{l}\text { 4-Auriferous quartz vein at contact } \\
\text { younger gabbro-granite }\end{array}$ & Intraplate environment & \\
\hline & 5- Small amounts in quartz veins of & & \\
\hline & $\mathrm{Sn}, \mathrm{W}, \mathrm{Ta}, \mathrm{Nb}$ mineralization & & \\
\hline & B. Disseminated type hosted in & Continental margin and intra- & \\
\hline & hydrothermally altered rock & plate & \\
\hline \multirow[t]{4}{*}{ Placer deposits } & A. modern placers & Intra plate environment & \\
\hline & 1- Alluvial gold in wadis & & \\
\hline & 2- Beach placers & & \\
\hline & B. Lithified placer & & \\
\hline
\end{tabular}

The most important recent gold activities in Egypt today are: El Sukkary area (Centamine Limited, Pharaoh gold mine) and Hamash area (Hamash Company). Table 3 presents the published information about the two areas [71].

In both areas, El-Sukkari and Hamash, commercial production has just started. It is planned that surface mining, open pit-open cast mining, will be the mining technique. These are the most economic mining techniques for such large, low grade (average gold content is $1.5 \mathrm{~g} / \mathrm{t}$ ) ores.

At Hamash, heap leaching will be used for dissolving the precious metals. The heap leaching will be preceded by crushing the run-of-mine ore and screening it to pass $10 \mathrm{~mm}$. This screened product will be agglomerated, using cement as a binder, and piled into heaps. The heaps will be sprayed with cyanide solution, $0.5 \%-1.0 \%$ concentration, at $\mathrm{pH} 10-11$ for about $80-100$ days. The pregnant solution will be passed on activated carbon to adsorb the precious elements. These elements will be stripped by hot cyanide solution. Gold winning will be carried out by electrowinning, followed by gold purification to obtain gold bullion containing more than $99.5 \%$ gold. Although the commercial production at Hamash has not started yet, pilot scale testing proved the viability of the process.

At El-Sukkari area, the crushed ore will be finely ground for agitation leaching. The pregnant cyanide solution will be treated in a manner similar to that in Hamash operation. The planned production rate at El Sukkari location is about 7 tons of gold per year.

The mineral processing plants in both locations are quite similar to the conventional world wide techniques. They are as advanced as they can be.

Recently, gold was discovered at Uwaynat area, G. Kamel and G. Nazar. The gold assay in this area is up to $14 \mathrm{~g} / \mathrm{t}[7,11,38,48]$. This area is recently bided for exploration and exploitation [73].

\subsection{Recent Bids for Gold Exploration and Exploitation}

There are Bids that were decided upon in 2007 for gold exploration and exploitation [73]. These bids are for the locations of: Um Balad, El-Fawakhier, Fatiri, Abu Mar-wat, Wadi Kariem, Hodine, Dungash, Uwaynat, and Barramiya.

As a matter of fact, a second bid for gold exploration and exploitation has been announced to the public for additional areas in the Eastern Desert.

The Future of gold mining and processing in Egypt is a bright one. Extensive exploration, mineralogical, petrographic, and processing research work is necessary for profitable exploitation of the gold resources in Egypt. 


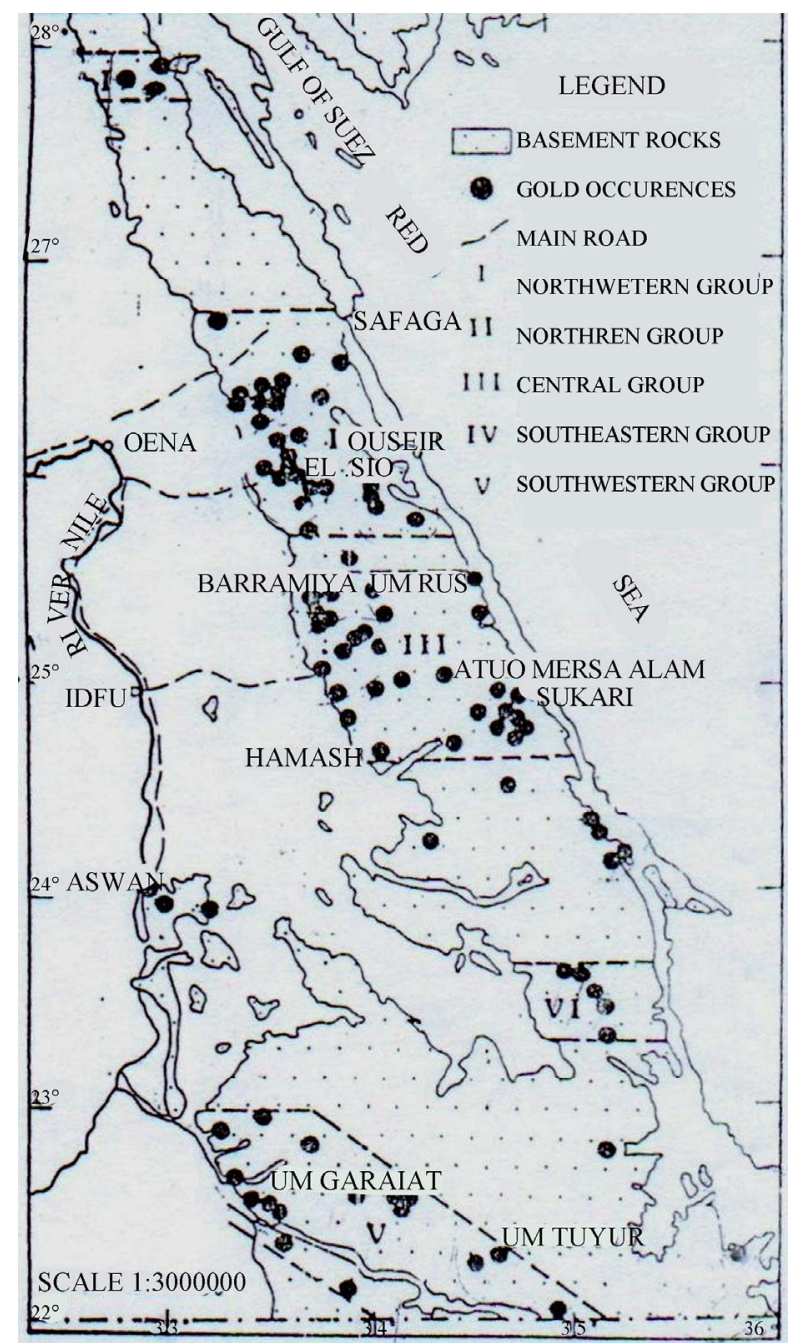

Figure 5. Gold mineralization areas as classified into five different regions $[68,69]$.

The history of more than 100 ancient gold workings is an indication of a huge gold source in the subsurface in the Eastern Desert.

\section{Industrial Metal Oxide Deposits}

\subsection{Tin-Tantalum-Niobium Deposits}

Tin-Tantalum-Niobium deposits are genetically related to late phase of granitic intrusions which generally form small and simple intrusions of alkali to peralkali intraplate anorogenic granites. Most of the Sn, W, Mo, $\mathrm{Nb}-\mathrm{Ta}, \mathrm{REE}, \mathrm{Be}$ and $\mathrm{F}$ deposits are associated with this type. The geological, mineralogical, and geochemical characteristics of this mineralization let many authors to propose the metasomatic origin [74]. The famous occurrences of this mineralization, which reach the economic level, are Abu Dabbab, Neuweibi, Muelha, Um Naggat, and Abu Rusheid. In the present article four areas are
Table 3. Recent active gold projects in Egypt. El Sukkary and Hamash gold areas information [27].

\begin{tabular}{|c|c|c|c|c|c|}
\hline \multicolumn{6}{|c|}{ a- EI Sukkary area } \\
\hline Information & \multicolumn{3}{|c|}{ Grade, $\mathrm{g} / \mathrm{t}$} & $\begin{array}{l}\text { Total amount } \\
\text { of rock, Mt. }\end{array}$ & $\begin{array}{l}\text { Gold content, } \\
\quad \mathrm{M} \mathrm{oz} .\end{array}$ \\
\hline \multirow{4}{*}{$\begin{array}{l}\text { Grades and } \\
\text { quantities }\end{array}$} & \multicolumn{2}{|c|}{ (Average) } & 1.42 & 64.53 & 2.944 \\
\hline & \multicolumn{2}{|c|}{ (More than) } & 2.07 & 33.43 & 2.223 \\
\hline & \multicolumn{2}{|c|}{ (More than) } & 16.50 & 0.15 & 0.082 \\
\hline & \multicolumn{2}{|c|}{ (More than) } & 40.40 & 0.15 & 0.2000 \\
\hline \multicolumn{3}{|c|}{$\begin{array}{c}\text { Total at cut off } \\
\text { grade } 0.5 \mathrm{~g} / \mathrm{t}\end{array}$ (Grand ave } & 1.48 & 64.53 & 3.226 \\
\hline \multicolumn{6}{|c|}{ b- Hamash areas } \\
\hline Area & $\begin{array}{l}\text { Average } \\
\text { grade, } \mathrm{g} / \mathrm{t}\end{array}$ & $\begin{array}{l}\text { Total a } \\
\text { of rock }\end{array}$ & $\begin{array}{l}\text { mount } \\
\text { k, Mt. }\end{array}$ & $\begin{array}{l}\text { Gold content, } \\
\text { M oz }\end{array}$ & $\begin{array}{l}\text { Recoverable } \\
\text { gold, } \mathrm{M} \mathrm{oz} *\end{array}$ \\
\hline Um Tondob & 0.8 & 12 & & 3.2 & 1.2 \\
\hline Ara & 1.5 & 5. & & 0.25 & 0.166 \\
\hline $\begin{array}{l}\text { Hamash } \\
\text { old mine }\end{array}$ & $2.0-4.0$ & 2.0 & & 0.20225 & 0.022 \\
\hline Abou Tarda & $1.5-5.0$ & 0.34 & 825 & 0.040825 & 0.32 \\
\hline Total proved & & 127 & & 3.693075 & 1.708 \\
\hline $\begin{array}{c}\text { Total } \\
\text { probable }\end{array}$ & $0.5-1.0$ & 2,0 & & 4.0 & 1.667 \\
\hline
\end{tabular}

mentioned in some details.

Abu Dabbab: It is located about $20 \mathrm{~km}$ North of Mersa Alam in the intersection of latitude $25^{\circ} 20^{\prime} 27^{\prime \prime} \mathrm{N}$ and longitude $34^{\circ} 32^{\prime} 30^{\prime \prime} \mathrm{E}$. The mineralization occupies an area of about $0.06 \mathrm{~km}^{2}$ forming cone-like shape of $100 \mathrm{~m} \times$ $130 \mathrm{~m}$. According to Sabet et al. [74], the tin, Tantalum, and Niobium mineralization is restricted to apogranite of the albitite type characterized by complex internal structure and interrelation of metasomatic facies. This granite muscovite-microcline-quartz-albite apogranite makes up the upper, central, and lower facies. The metasomatic facies of the fissure zones, the greizen zone, and mineralized quartz-feldspar veins are subordinate. Minerallogically, the ore consists of albite, microcline, quartz, muscovite, and topaz. Tantalite-columbite, pyrochlore, cassiterite, monazite, zircon, rutile, magnetite, galenite, and sphalerite are the main ore minerals.

The reserve was estimated by several authors. Sabet et al. [74] reported reserve as 20.6 million tons according tocategory $\mathrm{C} 2$ with $274 \mathrm{ppm} \mathrm{Ta}_{2} \mathrm{O}_{5}, 270 \mathrm{ppm} \mathrm{Nb}_{2} \mathrm{O}_{5}$ and $1080 \mathrm{ppm}$ Sn on the average, whereas Anonymous [75] stated that the rock reserves of Abu Dabbab is in the order of $40 \mathrm{Mt}$. Naim et al. [76] reviewed the Abu Dabbab ore reserves and calculated them as 7.3 million tons of ore containing $0.0266 \% \mathrm{Ta}_{2} \mathrm{O}_{5}, 0.0123 \% \mathrm{Nb}_{2} \mathrm{O}_{5}$, and $0.0165 \% \mathrm{SnO}_{2}$. Gabal Nuweibi ore Latitude $25^{\circ} 12^{\prime} N$ and Longitude $34^{\circ} 30^{\prime} \mathrm{E}$ : In this area, the ore is represented by 
fine dissemination of tantalite, columbite, with sub-ordinate casseterite, fluorite, muscovite, accessory garnet, zircon, and molybdenite in apogranite rocks. The reserves are estimated by Naim et al., [76] as 114.7 million tons of low grade ore with $161 \mathrm{ppm} \mathrm{Ta}_{2} \mathrm{O}_{5}$, and $91 \mathrm{~g} / \mathrm{t} \mathrm{Nb}_{2} \mathrm{O}_{5}$ Um Naggat: It is located in wadi Um Gheig, South of Qusseir. It is composed of albitized and greizenized pockets in granitic rocks. Tantalite and columbite occur as disseminated minerals in the pockets at assays of $0.022 \% \mathrm{Ta}_{2} \mathrm{O}_{5}$ and $0.2 \% \mathrm{Nb}_{2} \mathrm{O}_{5}$.

Abu Rusheid: The ore in this area is represented by disseminations of columbite, casseterite, monazite, xenotime, fluorite, zircon, thoragen, and microcline in mica apogranite rocks. The mineralized rock formation is the upper most part of the pssammitic gneiss that was subjected to metasomatic alteration. The analysis of core samples reflect that the ore contains $0.3 \% \quad \mathrm{Nb}_{2} \mathrm{O}_{5}$ and $0.033 \% \mathrm{Ta}_{2} \mathrm{O}_{5}$.

\subsection{Tin-Tungsten-Molybdenum Mineralization}

This type of mineralization was grouped by Hussein [32] as deposits associated with granitic rocks generally of G2 and G3 types. Igla is an example of the tin-tungsten ores near Mersa Alam, Eastern Desert [77].

Molybdenum mineralization: It occurs as disseminated and vein type at Gabal Gattar, Abu Marwa, Abu Harba, Um Disi and Homer Akarm [68,32]. Molybdenum minerals are associated with casseterite forming lateral zonation started by Molybdenum and followed by Tin minerals.

Tungsten mineralization: Tungsten minerals occur usually in association with tin minerals in Muelha and Igla where in the latter area, Sn reaches up to $0.5 \%$ and $\mathrm{W}$ up to $0.06 \%$. Also tungston associates $\mathrm{Sn}$ in $\mathrm{Abu}$ Dabbab. There are some areas where $\mathrm{W}$ is the principal mineral like in Abu Hammad, and Um Bisilla [32].

Tin mineralization: Tin occurs as disseminated and vein type in Muelha, Abu Hammad, Fatira, Abu Kharif, Abu Dabbab, and Nuweibi. At Muelha area the granite is subjected to metasomatism and the rock is albitized and altered to albite-microcline-quartz-Li-mica rock. Greisens form lenses and quartz veins with some impregnations of fluorite, cassiterite, powellite and $\mathrm{Cu}-\mathrm{Fe}$ sulphides.

Tin in placer deposits: Tin was reported in several areas in Eastern Desert especially in the areas around the main sources. Among these areas, Igla is the famous [77] which lies west of Mersa Alam. The geological reserves were calculated by Anwar et al. [78] as 245000 tons as category D3 and as 170000 tons Sn on D2 category.

Tin-tantalum-niobium ore at Abu Dabbab is a joint venture between Egypt and Gibbsland Co [79]. It is called Abu-Dabbab tantalum-tin-feldspar Project. The reserves are estimated by $40 \mathrm{Mt}$ of ore. The feasibility study is based upon a design throughput of $1.26 \mathrm{Mt} / \mathrm{y}$, which is expected to go up to $2 \mathrm{Mt} / \mathrm{y}$. In the first stage, the production is estimated to be about $195 \mathrm{t} / \mathrm{y} \mathrm{Ta}_{2} \mathrm{O}_{5}$ along with $980 \mathrm{t} / \mathrm{y}$ of tin metal during the first 20 years of production. The technical information about this joint venture is tabulated in Table 4, which presents the reserves in the close by locations in Abu Dabbab Valley. These reserves are large enough compared with similar worldwide Tin-tantalum-niobium ores in the world. It is now in the stage of development and site preparation [80]. It is planned that the ore will be mined by a surface mining technique. The capacity of the mineral processing units will be of about 2 million tons/year. The processing plant will consist of a size reduction section (crushing and grinding using jaw crushers, and a SAG mill), flotation, and magnetic separation followed by a dewatering system to produce concentrations of tin and tantalumniobium oxides products. The Ta-Nb Product will be used to produce $\mathrm{Ta}-\mathrm{Nb}$ ferroalloys, $\mathrm{Ta}$ oxide, $\mathrm{Nb}$ oxide, and ferroniobium alloys [80]. The $40 \mathrm{Mt}$ Abu Dabbab project is owned by the Egyptian registered company Tantalum Egypt,in which Gibbsland has a 50\% interest by way of an incorporated joint venture with the Egyptian Government.

\section{Titanium Ores}

The main source of titanium in Egypt is ilmenite. Ilmenite is present in a rock form in different localities in the Eastern Desert, and in the black sands on the Eastern part of the Mediterranean Coast. Titanium ores information are presented in Table 5.

\subsection{Ilmenite and Titaniferous Iron Ores (Rock Form)}

Ilmenite and titaniferous iron ores exist in Egypt in at least 10 localities with several dimensions. They are always associated with gabbroic rocks and formed by seg-

Table 4. Tin-Tantalum-Niobium ores information $[79,80]$.

\begin{tabular}{|c|c|c|c|c|}
\hline Area & Location & $\begin{array}{c}\text { Reserves, } \\
\text { M tons }\end{array}$ & $\begin{array}{l}\text { Produc., } \\
1000 \mathrm{t} / \mathrm{y}\end{array}$ & Average Content, \\
\hline \multirow{4}{*}{$\begin{array}{l}\text { Eastern } \\
\text { Desert }\end{array}$} & $\begin{array}{c}\text { Abou } \\
\text { Dabbab }\end{array}$ & 40 & - & $\begin{array}{c}0.027 \% \mathrm{Ta}_{2} \mathrm{O}_{5} \\
0.020 \% \mathrm{Nb}_{2} \mathrm{O}_{5} \\
0.017 \% \mathrm{Sn}\end{array}$ \\
\hline & Nuweibi & 115 & - & $\begin{array}{l}0.017 \% \mathrm{Ta}_{2} \mathrm{O}_{5} \\
0.015 \% \mathrm{Nb}_{2} \mathrm{O}_{5}\end{array}$ \\
\hline & Um Naggat & 25 & & $\begin{array}{l}0.022 \% \mathrm{Ta}_{2} \mathrm{O}_{5} \\
0.200 \% \mathrm{Nb}_{2} \mathrm{O}_{5}\end{array}$ \\
\hline & Abu Rusheid & $\mathrm{Na}$ & - & $\begin{array}{l}0.033 \% \mathrm{Ta}_{2} \mathrm{O}_{5} \\
0.300 \% \mathrm{Nb}_{2} \mathrm{O}_{5}\end{array}$ \\
\hline
\end{tabular}


regation. Among these areas are Abu Ghalaqa, Korabkanci, Kolmnab, Abu Dahr, and Um Effin. The two most economically promising deposits are those located at Abu Ghalaqa and Korabkanci.

Abu Ghalaqa ilmenite: This area lies $17 \mathrm{~km}$ South West of Abu Ghosoun port on the Red Sea coast and 100 $\mathrm{km}$ South of Mersa Alam city. The Ilmenite deposit is the largest among the ilmenite localities in Egypt. It is confined to gabbroic mass and occurs as a sheet-like body taking NW-SE and SE trend, and dips $30^{\circ}$ to the NE direction. The main ilmenite mass forms a big lens with exposed length about $300 \mathrm{~m}$, and an average width of about $150 \mathrm{~m}$. The detailed studies given by Hussein [32] revealed the presence of three types of ilmenite ore:

1-Red ore or oxidized zone on the surface,

2- Black ore or the main body, and

3-Disseminated ore

The mineralogical studies showed that the ore contains the following minerals:

$\begin{array}{lc}\text { Ilmenite } & 67.4 \%-68.8 \% \\ \text { Hematite } & 13 \%-18 \% \\ \text { Secondary hematite } & 15 \% \\ \text { Pyrite } & 0.13 \%-2.1 \% \\ \text { Other minerals } & 4 \%-11 \%\end{array}$

The overall chemical analysis of the ore is:

\begin{tabular}{|c|c|c|}
\hline Oxide & oxidized zone & fresh ore \\
\hline $\mathrm{TiO}_{2}$ & $37.09 \%-41.04 \%$ & $33.9 \%-37.65 \%$ \\
\hline $\mathrm{Fe}_{2} \mathrm{O}_{3}$ & $17.47 \%-23.0 \%$ & $6.34 \%-23.85 \%$ \\
\hline $\mathrm{FeO}$ & $27.93 \%-35.63 \%$ & $25.94 \%-31.33 \%$ \\
\hline $\mathrm{V}_{2} \mathrm{O}_{5}$ & $0.3 \% 1-0.38 \%$ & $0.29 \%-0.39$ \\
\hline
\end{tabular}

Korabkanci titano-magnetite ore: This area lies in the South East corner of Egypt. According to Makhlouf et al. [81], the ore occurs as seven layers concordant with layered mafic-ultramafic assemblage. These layers are of steep exposure that dips mostly $80^{\circ}-90^{\circ}$ to the East. The ore bands occur in parallel layers taking NNE-SSW and extend to about $2500 \mathrm{~m}$ with width $50-80 \mathrm{~m}$. The deposit exhibits medium to coarse grained texture. Mineralogically, it is composed of titano-magnetite, ilmenite, hematite, goethite, sulphides with some olivine gangue. The ore could be classified into massive and disseminated ore according to the percentage of opaque minerals in the rock. The massive part of the ore contains about $80 \%$ or

Table 5. Titanium and titaniferous iron ores [27,41].

\begin{tabular}{ccccc}
\hline Area & $\begin{array}{c}\text { Reserves, } \\
\mathrm{M} \text { tons }\end{array}$ & $\begin{array}{c}\text { Produc.,, } \\
1000 \mathrm{t} / \mathrm{y}\end{array}$ & $\begin{array}{c}\text { Average } \\
\text { Assay, } \\
\mathrm{Ti} \mathrm{O}_{2} \%\end{array}$ & $\begin{array}{c}\text { Associated } \\
\text { constituents }\end{array}$ \\
\hline $\begin{array}{c}\text { Red Sea } \\
\text { Coast }\end{array}$ & 40 & 120 & $30-38$ & $\begin{array}{c}\mathrm{Fe}_{2} \mathrm{O} 3, \mathrm{SiO}_{2}, \\
\text { Clays,Silicates } \\
\mathrm{SiO}_{2}, \mathrm{Mag} .\end{array}$ \\
$\begin{array}{c}\text { Mediterranean } \\
\text { Coast(Black } \\
\text { sands) }\end{array}$ & 400 & - & $2-3$ & $\begin{array}{c}\text { Rutile,Zircon, } \\
\text { monazite }\end{array}$ \\
\hline
\end{tabular}

more of opaque minerals.

\subsection{Black Sands}

Black sands in Egypt are beach placers deposited from the Nile stream during flood seasons reaching the Mediterranean Sea at river mouth. It spreads on the beach East of Rashid branch of the Nile and extends east to Rafah passing through El Arish coastal plains [40]. Figure 6 shows the geographic distribution of the black sands in Egypt. They spread along the Mediterranean Sea shore from Alexandria West to Rafah East. The black sands contain some economic minerals such as ilmenite, hematite, rutile, magnetite, zircon, garnet, and monazite. Some areas were studied in details and are briefly summarized here.

Rashid East: This area is located $6 \mathrm{~km}$ North East of Rashid, where the area is generally flat. Heavy concentrated black sands are deposited in a thin mantle near and parallel to the shoreline. The thickness of the deposited layer ranges from $0.5 \mathrm{~m}$ to more than $40 \mathrm{~m}$. The concentration and extension of the black sands to the West of Rashid are of negligible economic value. According to Naim et al. [41], the reserves of economic minerals at Rashid area are as follows (in 1000 tons):

$\begin{array}{lr}\text { Ilmenite } & 2087 \\ \text { Magnetite } & 1437 \\ \text { Hematite } & 214 \\ \text { Zircon } & 81 \\ \text { Rutile } & 29 \\ \text { Garnet } & 72 \\ \text { Monazite } & 31 \\ \text { Sulphides } & 86 \\ \text { Heavy silicates } & 1315\end{array}$

The ore shows lateral variations where the high concentrate occurs in the West and decreases gradually to the East.

Al Arish and Rommana areas: These areas extend from $2 \mathrm{~km}$ West of Al Arish to the East of Sabkhat El Bardaweel over an area of $18 \mathrm{~km}^{2}$. The total reserves in this area, to a depth of $1 \mathrm{~m}$, are about 88 million tons with 1.1 million tons as proved ore. The proved reserves to a depth of $10 \mathrm{~m}$ are estimated by 3 million tons of ore. The concentration and extension of the black sands to the East of Al Arish are negligible.

The ilmenite load, at Abu Ghalaqa, is about 100 meter above the wadi level and extends to more than $200 \mathrm{~m}$ below the wadi level. The wadi level itself is at about $240 \mathrm{~m}$ above Sea Level. The major lens covers an area of $150 \mathrm{~m} \times 300 \mathrm{~m}$. The present status of mining technology is an open cast above the wadi level $[1,40,82]$.

The Abu Ghalaqa ore is being mined by surface mining. The benches are drilled, charged, and blasted. To facilitate loading, transporting, and crushing, secondary 


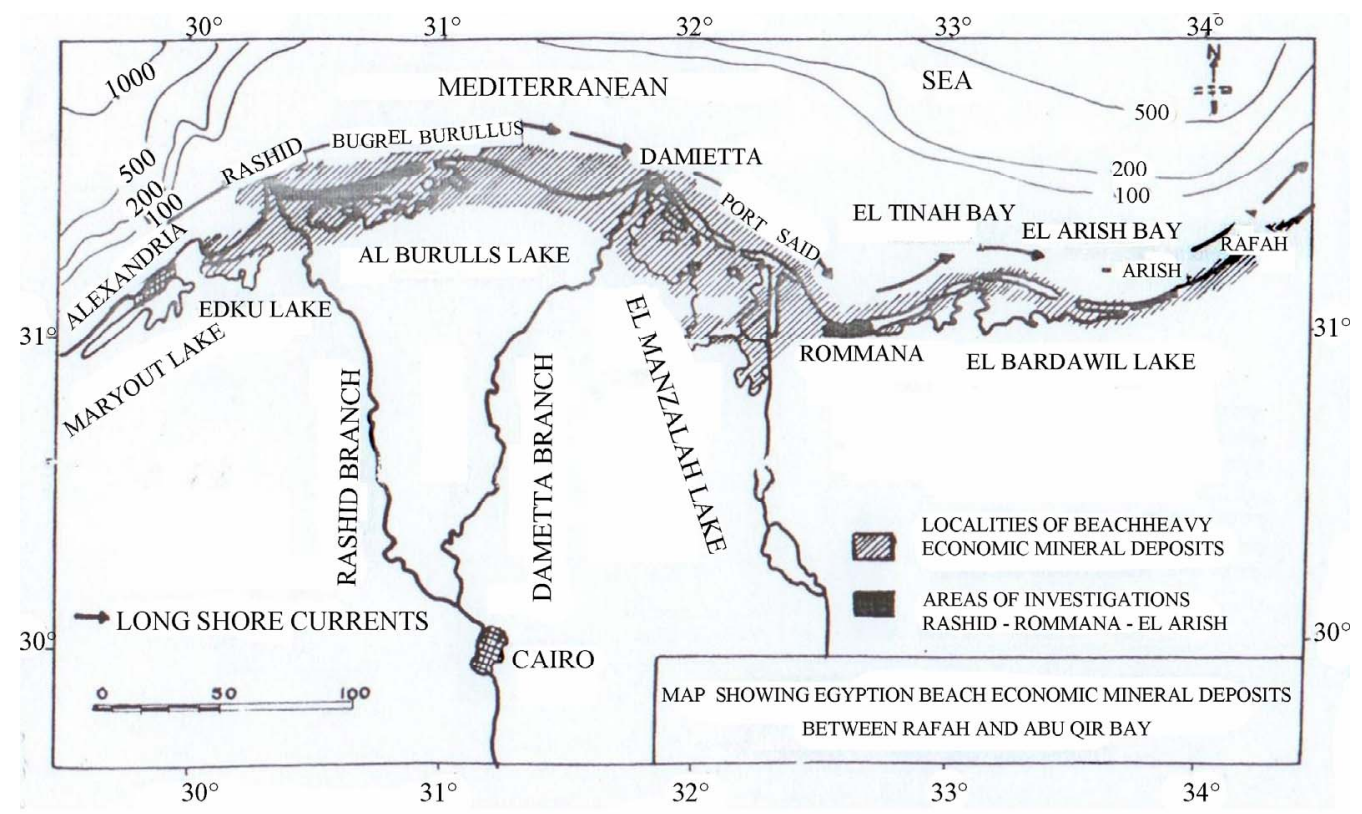

Figure 6. Locations of the Egyptian Black Sand deposits between Rashid and Rafah on the Mediterranean Sea Coast [41].

blasting is applied on the oversize boulders. The ore is transported to the upgrading plant near by (about $500 \mathrm{~m}$ ). In future it is thought to use underground mining for the lowed part of the load (below the Wadi level) to reduce the cost of overburden removal.

The grade of the ilmenite ore at Abou Ghalaqa is slightly upgraded by manual hand picking of some of the gangue minerals depending on difference in colors. The ore is then crushed and screened to produce different size fractions according to the end use. The only use for this ore at the time being is for coating the oil-transport pipes running under the sea water, i.e., is used as heavy gravel in the concrete used for coating the oil-pipes under sea water. Laboratory experiments, up to the pilot scale, show that gravity separation, magnetic separation, and flotation produce concentrates assaying up to $43 \% \mathrm{TiO}_{2}$. There are several researches for extracting titanium slag or titanium metal from the upgraded ore, but the results are not encouraging due to the low content of $\mathrm{TiO}_{2}$ in the concentrate.

Black sands are dredged or scraped, piled, and transported to a jungle of Humphrey spirals to scavenge out most of the green sands. The concentrate is sent to the processing plant for separating the heavy constituents [40,41].

For the black sands, there was a plant in Alexandria for concentrating the black sands and separating its various constituents. This continued until 1970, after which the plant was shut down due to technical problems, environmental considerations as well as market saturation for the products. Nowadays, there is a pilot plant at Rosetta for developing a proper flow sheet to produce market grade products.

The main flow sheet for black sand consists of a gravity separation step to get rid of most of the green sands, followed by a low intensity wet magnetic separator to separate magnetite. The non-magnetic fraction is oven dried to be prepared for the electrostatic separation step that separates ilmenite. In a second electrostatic step, rutile is separated. After separation of rutile, the rest is taken to shaking tables to separate garnet and monazite and reject the rest of the green sands.

\section{Manganese Ores}

Manganese ores occur in Egypt in two major localities beside other several small occurrences [83]. The economic deposits of manganese are Um Bogma in Sinai and Elba in South Eastern Desert.

Um Bogma area lies in Central Western Sinai Manganese occurs as lenses and lensoidal bodies with different dimensions within Carboniferous sediments of Um Bogma formation. The ore shows sudden contact with dolomitic rocks and reflects stratiform type [30]. Mart and Sass [84] classified the ore into two facies dolomite facies and silty facies and they are inclined to shallow marine environmental deposition of the ore on one hand. On the other hand Attia [83] and others believed that the ore was formed during metasomatic hydrothermal process. The more recent work again supports the sedimentation origin [32].

Elba Manganese ore occurs within sedimentary rocks of Miocene age in about 24 locations in Shalateen plain. 
Manganese forms vein like type striking N 120 and N 130 in a zone of $7 \mathrm{~km}$ width and $70 \mathrm{~km}$ long. El Shazly [30] proposed weathering products of basement rocks rich in manganese as a source of the ore which deposited in fissures and cracks with some replacement along fracture walls. Basta and Saleeb [85] suggested epigenetic origin in low temperature where manganese oxides prevailed and absence of silica, carbonate and sulphides which manifested in near surface deposition. Other Mn occurrences are recorded in Wadi Malik near Ras Banas and Abu Shaar El Qibli in Southern part of Esh El Mallaha range $[3,32]$. The reserves and production are given in Table 6.

Manganese is mined in the different localities by underground methods, mainly room and pillar. In the exposed outcrops it is mined by surface mining techniques. The iron oxides are highly disseminated in the manganese oxide matrix, which makes the possibility of upgrading the ore is limited.

The only processing steps carried out on the manganese ores are crushing and screening. The prepared ore is mixed with some imported high grade manganese ore and fed to the smelter at Abu Zonaima, Sinai to produce ferromanganese alloys [86]. The fines, under size fractions, are piled in dump areas. It is expected that agglomeration and magnetic roasting, followed by low intensity magnetic separation may improve the grade of the manganese ore in the rejected fines, which in turn may increase the manganese recovery.

\section{Sulfide Mineralization in Egypt}

\subsection{Lead-Zinc Deposits}

This type is located in Phanerozoic sediments and crops out in seven areas in the Southern part in the Eastern Desert on the Red Sea Coast namely: Zug El Behar, Asel, Wizr, Um Gheig, Abu Anz, Gabal El Rusas, and Ranga $[30,36,57,87]$. It is restricted to lower part of Gabal El Rusas Formation which unconformally located on the Precambrian rocks in Zug El Behar and Asel areas. In the other occurrences the mineralization belongs to Upper Abu Dabbab Formation.

The primary sulphides are galena, sphalerite, pyrite, marcasite which are transformed on the surface to cerusite, anglesite, smithosnite, hydrozincite, jarosite, and limonite. Many authors are inclined to propose that the replacement of limegrit by cold hydrothermal solutions as the main origin of this mineralization. El Shazly [30] and El Ramly et al. [68] suggested synsedimentary origin, whereas Hilmy et al. [88] pointed to the exhalative sedimentary origin. On the basis of detailed work on Um Gheig, Asel, and Zug El Behar areas, El Aref and Amstutz [89] classified the mineralization into two groups: 1) $\mathrm{Pb}-\mathrm{Zn}$ as filling type in Um Gheig and Wizr, and 2) stratiform galena in Zug el Behar and Asel. The ore is restricted on the filling mass extend along the rift taking NW-SE intercontinental rift and not necessarily to be related to magmatic activity accompanying the rift. The Geological Survey of Egypt estimates the reserves in Um Gheig as 1.5 million tons with an average assay of $13.8 \% \mathrm{Zn}$ and $2.3 \% \mathrm{~Pb}$.

\subsection{Copper Sediments}

Several occurrences of copper were recorded in Phanerozoic sediments in Centre and West Sinai as secondary malachite and in some places mixed with Manganese (90). The reserves are limited.

\subsection{Cu-Ni-Co Deposits}

This type of mineralization is well represented in Abu Swayel and El Geneina in South Eastern Desert. The ore is closely related to mafic-ultramafic and gabbro of ophiolitic rocks.

Abu Swayel deposit is located about $185 \mathrm{~km}$ South Aswan. The main mineralized zone contains massive and dissimenated deposit type being hosted in amphibolite rocks, surrounded by biotite schists which could be representing the metamorphosed equivalent of ophiolitic gabbro and basalt [32]. The main minerals are pyrite, pyrrhotite, chalcopyrite, pentlandite, violarite, and ilmenite. Malachite occurs in the oxidized zone. The reserves are estimated as 185000 tons containing $2.8 \% \mathrm{Cu}$ and $1.57 \% \mathrm{Ni}$ and minor concentration of Cobalt [32].

El Geneina deposit is located in the intersection of Latitude $23^{\circ} 57^{\prime} \mathrm{N}$ and Longitude $34^{\circ} 37^{\prime} \mathrm{E}$ where gossans with $\mathrm{Cu}$ and $\mathrm{Ni}$ do exist. Malachite and garnierite stained gossans are associated with thrust slicks of mafic rocks. Ore minerals are pyrite, pyrrohotite, and chalcopyrite. The metal assays are $0.17 \% \mathrm{Cu}$ and $0.38 \% \mathrm{Ni}$ [32].

Table 6. Manganese ores information [27].

\begin{tabular}{cccccc}
\hline Area & Location & Reserves, M tons & Produc., $1000 \mathrm{t} / \mathrm{y}$ & Average Content, $\mathrm{MnO}_{2}$ & Associated constituents \\
\hline \multirow{2}{*}{ Eastern } & Esh El-Mallahah & $\mathrm{Na}$ & $\mathrm{Na}$ & $35.8-45.14$ & \\
Desert & W. Ma'alik & $\mathrm{Na}$ & 120 & 42.17 & $\mathrm{Fe}_{2} \mathrm{O}_{3}, \mathrm{SiO}_{2}$, clays \\
& G.Elba \& Abou Ramad & $\mathrm{Na}$ & $\mathrm{Na}$ & 45.0 & \\
Sinai & Abou Zunima & 5 & 120 & 38 & $\mathrm{Fe}_{2} \mathrm{O}_{3}, \mathrm{SiO}_{2}$, clays \\
\hline
\end{tabular}




\subsection{Cu-Ni Sulphide}

This type of mineralization occurs in gabbro rocks at Akarm $\left(24^{\circ} 00^{\prime} \mathrm{N}\right.$ and $\left.34^{\circ} 17^{\prime} \mathrm{E}\right)$. The mineralization exhibits both massive and disseminated types within norite, melanorite, and peridotite. The surface expression clearly shows the presence of three zones of gossans which could be related to three sulphide bands. The total reserves of this location are estimated as 700000 tons with $0.95 \% \mathrm{Cu}-\mathrm{Ni}[32]$.

\subsection{Stratiform Massive Sulphides}

This type of mineralization is represented by a group of small deposits in South Eastern Desert, e.g., Um Samuki, Helgit, Maakal, Darheeb, Abu Gurdi, Egat, and Al Atshan.

Um Samuki deposit lies in the intersection of latitude $24^{\circ} 14^{\prime} \mathrm{N}$ and long $34^{\circ} 30 \mathrm{E}$. It is $\mathrm{Zn}-\mathrm{Cu}-\mathrm{Pb}$ deposit. The area is mainly built of cal-alkaline island arc volcanics andesite and their pyroclastics. As a result of these mineralization conditions, the area received intensive studies. These studies attribute the mineralization to epigenetic process, where it was introduced by hydrothermal solutions along shear zones developed by replacement of preexisting rocks. On the contrary of epigenetic hydrothermal deposition, Hussein et al. [91] and Hussein [32] believed that this deposit is a massive sulphide body which was deposited during the Abu Hamamid volcanics episode on the top of submarine volcanic vent system and the sedimentation took place conformally with the enclosing rocks at the interface between the volcanic pile and sea water. The ore bodies overlay a stock work of altered rocks resulting from intensive metasomatic effects induced by the ascending volcanic exhalation on the channel ways through which they ascended [91]. The ore body in the Western part assays $2.2 \% \mathrm{Cu}, 21.6 \% \mathrm{Zn}$, $0.5 \% \mathrm{~Pb}$ and $109 \mathrm{~g} / \mathrm{t} \mathrm{Ag}$ with total reserves of 200000 tons [92] while the Eastern part is less in metal content where $\mathrm{Cu}$ posses $1.8 \%, \mathrm{Zn} 13.6 \%$, and $\mathrm{Pb} 3.4 \%$.

There are no mining activities in the sulphide mineralization areas except at Um Ghaig where the production is at very small scale. Some of these localities were exploited by the Ancient Egyptians and used in manufacturing metallic alloys such as brass and bronze. The rest of the sulfide ores in Egypt exists in small quantities, which can not be exploited economically nowadays.

\section{Chromite Deposits}

Chromite deposits occur as small lenses of podiform within serpentinite rocks of ophiolitic sequences at Gabal Moqassem, Um El Tiyur, Sul Hamid, Um Krush, Wadi Himur, Abu Dahr, Wadi Ghadir, Um Khariga and others. Most of these locations lie South of Latitude $26^{\circ} \mathrm{N}$ [32]. The majority of these ores are exhausted. The origin of chromite is attributed to early crystallization followed by crystal settling from basic magma at spreading centers during the formation of new oceanic crust which tectonically emplaced during accretion prior to cratonization [32].

No large scale exploitation is reported in any of the mentioned chromite occurrences. It is well known that chromite ores can be beneficiated by gravity separation and/or flotation depending on the ore constituents and the economic liberation size.

\section{Possible Areas for Investment in Mineral Industry in Egypt}

The following areas are open for serious investment in the mineral industry, metallic commodities, in Egypt:

1) Mining and Mineral Processing of iron ores at: Uwaynat (Western Desert), Eastern Desert, Baharya Oases, and Aswan.

2) Integrated iron and steel industry.

3) Exploitation of ilmenite ores in the feasible areas.

4) Evaluation and exploitation of Beach Black Sands for their strategic hevy minerals.

5) Exploration, Mining, Processing, and Extraction of: gold, tin, tantalum, and niobium.

\section{Conclusions}

The mineral resources in Egypt are plenty. However, it could be multiples of the known reserves if the appropriate subsurface exploration technology is used. Extrapolation of the available geological data suggests that with some additional geological efforts, clear ideas could be obtained about new mineral findings and/or extension of the existing deposits. As has been presented above, the simple primitive mining and mineral processing techniques limit the production capacity and produce inferior quality products, which lead to waste of resource, high cost of extraction, and low quality product.

Most of the metallic mining activities in Egypt are in the form of small operations, except for iron ore, which is reflected on the production cost being high. The most that is being done on any of the exploited commodities to upgrade or clean them is crushing, grinding, screening and sometimes grading and/or classification. Very little up-to-date technology in this area is being adopted. The concept of added value in the mineral industry in Egypt is almost missing. As a result, the low grade mineral products from such simple treatment are being marketed locally or exported. Consequently, the exported low grade mineral commodities are sold at ridiculously low prices because of reluctance to up date the technology. It is recommended that large scale mining operations and processing plants, on the bases of advanced technology, are to be introduced and implemented in the mineral in- 
dustry in Egypt. These will lead to improved quality, lower cost products, and more organized and interrelated mining systems.

\section{Acknowledgements}

The Authors would like to thank their colleagues who offered all kinds of help to them. Among those are Dr. A. A. Negm, Dr. M. A. El Wageeh, Dr. A. Dardir, and Mr. Wafae W. Ghobrial. They provided the Authors with valuable information, and discussed the scientific material with them. Thanks are also extended to Dr. G. Ozbayoglu and Dr. A. I. Arol from the Middle East Technical University at Ankara, Turkey for suggesting the topic and inviting one of the Authors, Dr. Abouzeid, to present the content of this article at their $11^{\text {th }}$ International Mineral Processing Symposium at Belek-ANTALYA, TURKEY (October, 2008). Great thanks and appreciation are due to Miss. Eanass A. Abouzeid for her help in preparing the Figures and putting the manuscript in its final form.

\section{REFERENCES}

[1] M. A., Ghonaim, "Present and Future of the Mining Industry in Egypt," Egyptian Geological Society, Vol. 17, 1978, pp. 35-46.

[2] A.-Z. M. Abouzeid, "Maximization of Added Value in Mineral Processing," 9th International Mining, Petroleum, and Metallurgical Conference, Cairo University, Cairo. February 2005, pp. 135-156.

[3] R. Said, "The Geology of Egypt," Taylor and Francis Publishers, London, 1990.

[4] A. Richter, "Geologie der Metamorphen und Magmatischen Gesteine in Gebiet Zwischen Gebel Uwaynat und Gebel Kamel, SW Agypten, NW Sudan," Berl. Geowiss. Agh, Vol. 73, 1986, pp. 1-201.

[5] A. Richter and H. Schandelmeier, "Precambrian Basement Inliers of Western Desert, Geology, Petrology, and Structural Evolution," In: R. Said, Ed., Geology of Egypt, Taylor and Francis, 1990, pp. 185-250.

[6] EGPC and CONOCO, "Egyptian General Petroleum Corporation and CONOCO," A geological Map of Egypt, 1987.

[7] G. Naim, A. M. Khalid, G. M. Said, S. Shaaban, A. Hussein and M. El Kady, "Banded Iron Formation Discovery at West Gabal Kamel and Its Gold Potentiality, Western Desert," Annals of the Geological Survey of Egypt, Vol. 21, 1998, pp. 303-330.

[8] J. Klerkx, "Age and Metamorphic Evolution of the Basement Complex around Gabal Aluwaynat," In: M. J. Salem and M. T. Busserawil, Eds., The Geology of Libya, Academic Press, London, 1980, pp. 901-906.

[9] M. Sultan, Z. El Alfy and K. Tucker, "U-Pb (Zircon) Ages from the Uweinat Area," Abstracts of Centennial of EGSMA, Cairo, 1996.
[10] A. O. Abu Salem, "Geology and Mineralogy of the Basement Rocks of West Gabal Kamel area," M.Sc.Thesis, Al Azhr University, 2003, p. 90.

[11] M. Khattab, O. R. Greiling, A. M. Khalid, M. Said, A. Kontany, A. Abu Salem, et al., "Uwaynat Banded Iron Formation (SW Egypt) Distribution and Related Gold Mineralization," Annals of the Geological Survey of Egypt, Vol. 25, 2002, pp. 343-364.

[12] M. F. Abdel Fattah, "Petrological and Geochemical Studies on the Basement Rocks of Northeast Gabal Uwaynat Area, Western Desert, Egypt," 2005, PhD Thesis Suez Canal University, p. 245.

[13] D. B. Stoeser and V. F. Camp, "Pan African Micro Plate Accretion of the Arabian Shield," Geological Society of America Bulletin, Vol. 96, 1985, pp. 817-826. doi:10.1130/00167606(1985)96<817:PMAOTA $>2.0 . C O 2$

[14] A. Kroner, R. Greiling, T. Reischamann, I. R. Hussein, R. Stern, S. Durr, et al, "Pan African Crustal Evolution in the Nubian Segment of Southeast Africa," In: A. Kroner A. Ed., Proterozoic Lithosphere Evolution, American Geophysical Union, Geodynamic series, Washington D.C. Vol. 17, 1987, pp. 1611-1634.

[15] M. A. El Sharkawy and R. El Bayoumi, "The Ophiolites of Wadi Ghadir Area, Eastern Desert, Egypt," Annals of the Geological Survey of Egypt, Vol. 9, 1979, pp. 125135.

[16] M. G. Abdel Salam and R. J. Stern, "Suture and Shear Zones in the Arabian-Nubian Shield," Journal of African Earth Science, Vol. 31, 1996, pp. 289-310.

[17] A. A. Abdel Meguid, "Late Proterozoic Pan African Tectonic Evolution of the Egyptian Part of the ArabianNubian Shield," Middle East Research Centre, Ain Shams University, Vol. 6, 1992, pp. 13-28.

[18] N. Sturchio, M. Sultan, P. Sylvester, R. Batiza, C. Hedge and A. A. Abdel Maguid, "Geology, Age, and Origin of Meatiq Dome: Implications for the Precambrian Stratigraphy and Tectonic Evolution of the Eastern Desert of Egypt," Fac. Earth Sc. Bull., King AbdulAziz University, Jeddah, Saudi Arabia, Vol. 6, 1983, pp. 127-143.

[19] A. A. Hussein, M. Ali and M. F. El Ramly, "A Proposed New Classification of the Granites of Egypt," Journal of Volcanology and Geothermal Research, Vol. 14, 1982, pp. 187-198. doi:10.1016/0377-0273(82)90048-8

[20] E. M. El Shazly, T. H. Dixon, A. E. J. Engel, A. A. Abdel Meguid and R. J. Stern, "Late Precambrian Crustal Evolution of Afro-Arabia from Oceanic arc to Craton, Egypt," The Journal of Geology, Vol. 24, No. 14, 1980, pp. 101-121.

[21] B. Grothous, D. Eppler and R. Ehrlich, "Depositional Environment and Structural Implications of the Hammamat formation, Egypt," Annal of Geological Survey of Egypt, Vol. 9, 1979, pp. 564-590.

[22] M. F. El Ramly and A. A. Hussein, "The Ring Complex of the Eastern Desert of Egypt," The Journal of African Earth Sciences, Vol. 3, 1985, pp. 77-82. doi:10.1016/0899-5362(85)90024-7

[23] B. Issawi, M. El Hinawi, M. Francis and A. Mazhar, "The 
Phanerozoic Geology of Egypt, A geodynamic Approach," Geological Survey of Egypt, 1999, p. 76.

[24] L. L. Sloss, "Global Sea Level changes: A View from the Craton," Geological and Geophysical Investigations of Continental Margins, A. A. P. G. Memorial, Vol. 29, 1979, pp. 461-467.

[25] F. B. Van Houten, "Latest Jurassic-Early Cretaceous Regressive Facies," In: A. A. Craton and P. G. Bull, Eds., Northeast Africa, Vol. 64, 1980, pp. 857-867.

[26] J. Ball, "Contribution to the Geography of Egypt," Geological Survey of Egypt, 1952, p. 308.

[27] A.-Z. M. Abouzeid and M. A. El Wgeeh, "Mineral Industry in Egypt-State of the Art," 11th International Mineral Processing Symposium, Belek, Antalya, Turkey. 2008, pp. 1-27.

[28] G. Kochine and F. A. Bassyuni, "Mineral Resources of the UAR, Part I, Metallic Minerals," Internal Report No. 18/19/68, Geological Survey of Egypt, 1968, p. 35.

[29] A. S. Amin, "Geological Features of Some Mineral Deposits in Egypt," Bulletin De Institute du Desert, Egypt, Vol. 1, 1955, pp. 208-239.

[30] E. M. El Shazly, "Classification of Egyptian Mineral Deposits," Egyptian Journal of Geology, Vol. 1, No. 1, 1957, pp. 1-20.

[31] T. G. Ivanov, I. Shalaby and A. A. Hussein, "Metallogeneic Characteristics of South Eastern Desert, Egypt," Annal of Geological Survey of Egypt, Vol. 3, 1973, pp. 139-166.

[32] A. Hussein, "Mineral Deposits," In: R. Said, Ed., The Geology of Egypt, Taylor and Francis Publishers, London, 1990, pp. 511-566.

[33] M. S. Garson and I. Shalaby, "Precambrian Lower Paleozoic Plate Tectonics and Metallogenesis in Red Sea Region," The Geological Association of Canada, Special Issue, 1976, pp. 537-596.

[34] N. S. Botros and A. M. Noor, "Mineral Deposits in the Eastern Desert of Egypt, an Expression of two Major Episodes with Distinct Magmatic and Tectonic Characteristics," Annal of Geological Survey of Egypt, Vol. 30, 2008, pp. 249-274.

[35] W. W. Ghobrial, "Iron Ores in Egypt," Personal Contact, 2008.

[36] W. W., Ghobrial, "Lead and zinc in Egypt," Personal Contact, 2008.

[37] W. W. Ghobrial, "Developing of Mineral Resources in Egypt," Personal Contact, 2008.

[38] A. M. Khalid and A. A. Diaf, "Geological and Geochemical Exploration for Gold and REE at Jabal Nazar and Jabal Arkenu, Egypt-Libya," Proceedings of Geological Survey, Egypt, 1996, pp. 425-446.

[39] A. M. Khalid, O. R. Greiling, M. M. Said, A. Megahed, G. Shaaban, M. Micheal, et al., "South Western Desert BIF. Laboratory Studies and Gold Extraction Tests," Annal of Geological Survey of Egypt, Vol. 25, 2002, pp. 315-332.

[40] M. A. Hassan, "Black Sands Project," A Briefing to the
Egyptian Association for Mining and Petroleum, Nuclear Material Authority, Cairo, June 12 2003, p. 21.

[41] G. Naim, E. T. El Melegy and A. El Azab, "Black Sand Assessment," The Egyptian Geological Survey, 1993, p. 67.

[42] Hunting Geophysical Co. Geology of Al Uwaynat, East. Libya, IRC Tripoli. Internal Report, 1974, p. 190.

[43] N. Sh. Botros, "Geological and Geochemical Studies on Some Gold Occurrences in the North Eastern Desert," Ph.D. Thesis, Zagazig University, Zagazig, Egypt. 1991, p. 146.

[44] A. Dardir and K. El Chimi, "Geology and Geochemical Exploration for Gold in the Banded Iron Formation of Um Nar Area, Central Eastern Desert, Egypt," Annal of Geological Survey of Egypt, Vol. 18, 1992, pp. 103-111.

[45] M. F. El Ramly, M. K. Akaad and A. H. Rasmy, "Geology and Structure of Um Nar Iron Deposit," Special Paper, No. 28, Geological Survey Egypt, 1963, p. 29.

[46] P. K. Sims and H. James, "Banded Iron Formation of Late Proterozoic Age in the Central Eastern Desert of Egypt, Geology and Tectonic Setting," Economic Geology, Vol. 79, 1984, pp. 1777-1784. doi:10.2113/gsecongeo.79.8.1777

[47] A. El Dougdoug, M. F. Awadallah and Z. Hamimi, Textural Relations in the Banded Iron Formation Facies of Gebel El Hadid Area, Central Eastern Desert, Egypt," Annal of Geological Survey of Egypt, Vol. 15, 1985, pp. 31-44.

[48] M. Said, A. M. Khalid, M. El Kady, A. Abu Salem and S. Ibrahim, "On the Structural Evolution of Banded Iron Formation of Gabal Kamel and Its Role in the Gold Mineralization," Annal of Geological Survey of Egypt, Vol. 21, 1998, pp. 345-352.

[49] D. D. Klemm, "The Formation of Paleoproterozoic Banded Iron Formation and Their Associate Fe and $\mathrm{Mn}$ Deposits with Reference to Griqualand West Deposits, South Africa," The Journal of African Earth Sciences, Vol. 30, No. 1, 2000, pp. 1-24. doi:10.1016/S0899-5362(00)00005-1

[50] E. Basta and H. Amer, "El Gidida Iron Ores and Their Origin, Bahariya Oases, Egypt," Economic Geology, Vol. 64, 1969, pp. 424-444. doi:10.2113/gsecongeo.64.4.424

[51] A. A. El Bassyony, "Geology of the Area between Gara El Hamra, Ghard El Moharik and El Harra Area, Bahariya Oases, Egypt," M. Sc. Thesis, Cairo University. 1970, p. 98.

[52] A. A. El Bassyony, "Geological Setting and Origin of El Harra Iron Ores, Bahariya Oases, Western Desert, Egypt," Annal of Geological Survey of Egypt, Vol. 23, 2000, pp. 213-222.

[53] S. Akaad and B. Issawi, "Geology and Iron Deposits of Bahayria Oasis," The Egyptian Geological Survey, No. 18, 1963, p. 300.

[54] M. A. El Sharkawy, M. A. Higazi and M. A. Khalil, "Three Probable Genetic Types of Iron Ore at El Gadida 
Mine, Western Desert," Egyptian Journal of Geology, Vol. 31, 1987, pp. 1-2.

[55] M. M. El Aref and Z. Lotfi, "Genetic Karst Significance of the Iron Ore Deposits of El Bahariya Oases, Western Desert," Annal of Geological Survey of Egypt, Vol. 15, 1985, pp. 1-30.

[56] M. A. Khalil, "Geological and Mineralogical Studies on the Northeastern Part of El Bahariya Oases, Western Desert, Egypt,” Ph. D. Thesis. Al Azhar University, 1995, p. 237.

[57] E. M. El Shazly and A. A. Hassan, "The Results of Drilling in the Iron Ore Deposit of Ghorabi, Bahariya Oases, Western Desert," Survey Depart, 1962, p. 41.

[58] D. Neev, K. J. Hall and M. J. Saul, "The Pelasium Megashear System across Africa and Associated Lineament Swarms," Journal of Geophysical Research, Vol. 87, No. B2, 1982, pp. 1015-1030. doi:10.1029/JB087iB02p01015

[59] B. Issawi, "Geology of the South Western Desert of Egypt," Annal of Geological Survey of Egypt, Vol. 11, 1981, pp. 57-66.

[60] M. I. Attia, "Topography, Geology, and Iron Ore of the District East of Aswan," The Egyptian Geological Survey, 1955, p. 262.

[61] EISC, Egyptian Iron and Steel Co. Projected Plan for 2007/2008. 2007, p. 39.

[62] M. A. Khalid, M. M. Said, A. El Naggar and N. Moselhy, "Geological and Geochemical Exploration at Gabal Kulyeit and Its Environs, South Eastern Desert, Egypt," Annal of Geological Survey of Egypt, Vol. 23, 2000, pp. 223-233.

[63] Kh. Oweiss and A. M. Khalid, "Geochemical Prospecting at Um Qareiyat Gold Deposit, South Eastern Desert, Egypt," Annal of Geological Survey of Egypt, Vol. 17, 1991, pp. 145-151.

[64] A. M. Khalid and Kh. Oweiss, "Results of Mineral Exploration Programs in South Eastern Sinai, Egypt," Annal of Geological Survey of Egypt, Vol. 20, 1995, pp. 207-220.

[65] A. M. Khalid and Kh. Oweiss, "Geochemical Exploration for Gold at Wadi Kid Area, Southern Sinai, Egypt," Annal of Geological Survey of Egypt, Vol. 20, 1995, pp. 333-342.

[66] B. B. Nasr, M. S. Masoud, H. El Sherbini and A. Makhlouf, "Some New Occurrences of Gold Mineralization, Eastern Desert, Egypt," Annal of Geological Survey of Egypt, Vol. 21, 1998, pp. 331-344.

[67] I. Khalaf and Kh. Oweiss, "Gold Prospection in the Environs of Sukkari Gold Mine, Central Eastern Desert," Annal of Geological Survey of Egypt, Vol. 23, 1993, pp. 223-233.

[68] M. F. El Ramly, S. S. Ivanov and G. G. Kochin, "Studies on Some Mineral Deposits of Egypt, Part I, Section A, Article 3, Tin-Tungsten Mineralization, Eastern Desert, Egypt," The Egyptian Geological Survey, 1970, pp. 120-145.

[69] M. F. El Ramly, S. S. Ivanov and G. G. Kochin, "The Occurrence of Gold in the Eastern Desert of Egypt," In: O. Moharm et al. Eds., Studies on Some Mineral Deposits of Egypt, The Egyptian Geological Survey, 1970, pp. $53-$ 64.

[70] N. Sh. Botros, "A New Classification of the Gold Deposits of Egypt," The Journal of African Earth Sciences, Ore Geology Review, Vol. 4, No. 2, 2004, pp. 1-35.

[71] EGSMA, "Egyptian Geological Survey and Mining Authority, Egypt," Results of Prospecting and Provisory Work for Gold at Barramiya, Sukkary, Um Nar Prospects, Internal Report No. 19/77, 1977.

[72] EGSMA, "Egyptian Survey and Mining Authority, Egypt," Results of Prospecting and Evaluation Carried out at the Eastern Flank of the Barramiya Gold Ore Deposit in 1976-1977, Internal Report No. 16/78, 1978.

[73] EMRA, "Egyptian Mineral Resources Authority," Results of 2006 1st International Bid Round for Gold Exploration and Exploitation in Egypt, Egypt, 2006.

[74] A. H. Sabet, V. B. Tsogoev, L. M. Baburin, A. Riad, A. Zakhari and L. Armanious, "Geologic Structure and Laws of Localization of Tantlum Mineralization at Neweibi Deposit," Annal of Geological Survey of Egypt, Vol. 6, 1976, pp. 119-156.

[75] Anonymous, "Egyptian Tin and Tantalum," Mining Magazine, October 2004.

[76] G. M. Naim, A. T. El Melegy and Kh. Soliman, "Tantalum-Niobium-Tin Mineralization in Central Eastern Desert, Egypt, a Review," Proceedings of Geological Survey, 1996, pp. 599-622.

[77] H. Sadek, "Report on Igla Tin Deposit, Eastern Desert. Mines and Quarries Depart," Internal Report, Cairo, Egypt, 1944

[78] T. Anwar, M. A. Morsy, A. I. Arslan and M. A. El Maky, "Estimation of the Probable Geological Reserve of Tin in the Igla Area, Eastern Desert, Egypt," Arab Mining and Petroleum Association Conference, Ismalia, Egypt, 1983, p. 39

[79] Gippsland Limited, “Tantalum Industry Overview,” 2005, Annual Report, p. 58.

[80] Gippsland Limited, Annual Report, 2005, p. 55.

[81] A. Makhlouf, N. Y. Beniamin, M. M. Mansour, S. A. Mansour and H. El Sherbini, "Mafic-Ultra Mafic Intrusion of South Korabkanci Area with Emphasis on Titanomagnetite Ores, South Eastern Desert, Egypt," Annal of Geological Survey of Egypt, Vol. 30, 2008, pp. 1-20.

[82] El Nasr Mining Co. Monetary Status for Plan for 2006/2007, 2007.

[83] M. I. Attia, "Manganese deposits of Egypt," The 20th International Geological Congress, Mexico, 1956, pp. 143-171.

[84] S. Mart and E. Sass, "Geology and Origin of Manganese Ore of Um Bogma, Sinai," Economic Geology, Vol. 67, 1972, pp. 145-155. doi:10.2113/gsecongeo.67.2.145

[85] E. Z. Basta and G. S. Saleeb, "Elba Manganese Ore and Their Origin, South Eastern Desert, Egypt," Mineralogical Magazine, Vol. 38, 1971, pp. 235-244. 


\section{doi:10.1180/minmag.1971.038.294.13}

[86] ESAC, "Egyptian Steel Alloys Co. Projected Plan for 2007-2008," 2007, pp. 1-46.

[87] E. M. El Shazly, A. Mansour, M. S. Afia and M. G. Ghobrial, "Miocene Lead and Zinc Deposits in Egypt," 20th International Geological Congress, Mexico, 1959, pp. 119-134.

[88] M. E. Hilmy, F. M. Nakhla and M. Ramsy, "Contribution to the Mineralogy, Geochemistry, and Genesis of the Miocene $\mathrm{Pb}-\mathrm{Zn}$ Deposits in Egypt," Chemie der Erde, Vol. 31, 1972, pp. 373-390.

[89] M. M. El Aref and C. C. Amstutz, "Lead-Zinc Deposits along the Red Sea Coast of Egypt," Monograph Series on
Mineral Deposits, Gebruder Bornt Raeger, Stutgart, No. 21, 1983, p. 103.

[90] M. E. Hilmy and M. Mohsen, "Secondary Copper Minerals from West Central Sinai," Egyptian Journal of Geology, Vol. 9, 1965, pp. 1-12.

[91] A. A. Hussein, I. M. Shalaby, M. A. Gad and A. Rasmy, "On the origin of $\mathrm{Zn}-\mathrm{Cu}-\mathrm{Pb}$ Deposits at Um Smuki, Eastern Desert, Egypt," 15th Annual Meeting, Geological Society, 1977.

[92] D. L. Searle, G. S. Carter and I. M. Shalaby, "Mineral Exploration at Um Samuki," U.N. Technical Report No. 36-76, Documentation Centre of Egyptian Geological Survey, Egypt, 1976. 